\title{
The Role of the Gut Microbiome in Colorectal Cancer Development and Therapy Response
}

\author{
Lidia Sánchez-Alcoholado ${ }^{1,+}{ }^{,}$Bruno Ramos-Molina ${ }^{2,+} \oplus$, Ana Otero ${ }^{3}$, Aurora Laborda-Illanes ${ }^{1}$, \\ Rafael Ordóñez ${ }^{3}$, José Antonio Medina ${ }^{3}$, Jaime Gómez-Millán ${ }^{3, *}$ and \\ María Isabel Queipo-Ortuño ${ }^{1}$ (I) \\ 1 Unidad de Gestión Clínica Intercentros de Oncología Médica, Hospitales Universitarios Regional y Virgen \\ de la Victoria. Instituto de Investigación Biomédica de Málaga (IBIMA)-CIMES-UMA, 29010 Málaga, Spain; \\ 1.s.alcoholado2@gmail.com (L.S.-A.); auroralabordaillanes@gmail.com (A.L.-I.); \\ maribelqo@gmail.com (M.I.Q.-O.) \\ 2 Departamento de Cirugía Digestiva, Endocrina y Transplante de Órganos Abdominales, Instituto Murciano \\ de Investigación Biosanitária (IMIB-Arrixaca), 30120 Murcia, Spain; brunoramosmolina@gmail.com \\ 3 Unidad de Gestión Clínica de Oncología Radioterápica, Hospital Universitario Virgen de la Victoria. \\ Instituto de Investigación Biomédica de Málaga (IBIMA), 29010 Málaga, Spain; \\ ana.otero.rom@gmail.com (A.O.); rafaelordm@gmail.com (R.O.); jmedinacarmona@gmail.com (J.A.M.) \\ * Correspondence: jaimegomezmillan@gmail.com \\ + These authors contributed equally.
}

Received: 22 April 2020; Accepted: 28 May 2020; Published: 29 May 2020

\begin{abstract}
Colorectal cancer (CRC) is the third most common cancer worldwide and the leading cause of cancer-related deaths. Recently, several studies have demonstrated that gut microbiota can alter CRC susceptibility and progression by modulating mechanisms such as inflammation and DNA damage, and by producing metabolites involved in tumor progression or suppression. Dysbiosis of gut microbiota has been observed in patients with CRC, with a decrease in commensal bacterial species (butyrate-producing bacteria) and an enrichment of detrimental bacterial populations (pro-inflammatory opportunistic pathogens). CRC is characterized by altered production of bacterial metabolites directly involved in cancer metabolism including short-chain fatty acids and polyamines. Emerging evidence suggests that diet has an important impact on the risk of CRC development. The intake of high-fiber diets and the supplementation of diet with polyunsaturated fatty acids, polyphenols and probiotics, which are known to regulate gut microbiota, could be not only a potential mechanism for the reduction of CRC risk in a primary prevention setting, but may also be important to enhance the response to cancer therapy when used as adjuvant to conventional treatment for CRC. Therefore, a personalized modulation of the pattern of gut microbiome by diet may be a promising approach to prevent the development and progression of CRC and to improve the efficacy of antitumoral therapy.
\end{abstract}

Keywords: colorectal cancer; gut microbiota; dysbiosis; inflammation; short-chain fatty acids; polyamines; dietary fiber; polyunsaturated fatty acids; polyphenols; probiotics

\section{Introduction}

Microbiota is composed of different bacterial populations with a mutualistic relationship that reside in the epithelial barriers of different organs in the host. Microbiota is a metabolically active ecosystem that interacts with epithelial and stromal cells, with a critical role in human health. Microbiota carries out different functions such as the production of diverse important metabolites, the prevention of infestation by pathogens, and the control of the overgrowth of some bacterial groups to prevent the 
modulation of the local environment by toxic bacteria [1]. In addition, microbiota is essential for the activation of the host immune system [2].

The quantity and diversity of microbial species in the gut increase longitudinally from the stomach to the colon, being the colonic microbiota the most dense and metabolically active community [3]. Although the composition of microbiota is influenced by genetics [4] and may be considered relatively stable within healthy adults over time [5], there is a large variation in the microbiota composition among individuals; this variation is conditioned by different external environmental factors such as diet, chemical exposure, and antibiotic/medication consumption. Dietary changes have been shown to have significant effects in gut microbiota, and the switching from a high-fat/low-fiber diet to a low-fat/high-fiber diet may cause important changes in the gut microbiota within 24 hours [6].

In the last decade numerous works have established a clear relationship between alterations in the gut microbiota composition and diverse human pathologies. In particular, obesity and associated metabolic disorders (e.g., type 2 diabetes and non-alcoholic fatty liver), autoimmune diseases (e.g., type 1 diabetes and inflammatory bowel disease), and several types of cancer are characterized by changes in the microbiome and gut dysbiosis [7].

The gut microbiota produces a diverse metabolite repertoire that may harm or benefit the host. Alterations in the intestinal bacteria balance could lead to changes in the levels of gut microbial metabolites such as short-chain fatty acids (SCFAs), polyphenols, vitamins, tryptophan catabolites and polyamines [8], which could be related to the pathogenesis of the human diseases described above. In particular, abnormal levels of SCFAs and molecules related to the metabolism of amino acid like polyamines have been involved in cancer progression and metastasis in different types of tumor [9].

In this review we discuss the potential role of gut microbiota in the carcinogenesis of colorectal cancer (CRC), the possible role of bacterial metabolites in CRC development and progression, and the influence that certain dietary mediators exert over the intestinal microbiota and CRC risk.

\section{Gut Microbiota and CRC}

\subsection{Gut Microbiota Composition in CRC}

CRC is the third most common cancer worldwide; nevertheless its exact aetiology is still unknown [10]. Most of the CRC cases are sporadic (nearly 90\%), and some genetic and environmental factors have been identified as potential risk factors. Lifestyle factors that increase the risk of CRC in developing countries include physical inactivity, smoking, unhealthy dietary habits (e.g., diets rich in processed and red meat, high fat diets, low intake of fibre), alcohol consumption, and obesity [11-13]. Importantly, all these enviromental factors are able to produce changes in the gut microbiota composition [14].

Emerging evidence suggests that in animal models gut microbiota may contribute to CRC development through the production of microbial metabolites that interact with the host-immune system and induce the release of genotoxic virulence factors $[1,2,15,16]$. Recent works have reported that patients with CRC display a lower bacterial diversity and richness in fecal samples and intestinal mucosa compared to healthy individuals $[17,18]$. In addition, CRC patients show significant alterations in specific bacterial groups with a potential impact on mucosal immune response with respect to healthy controls [18]. In particular, CRC patients exhibit a significant increase in Bacteroides fragilis, Fusobacterium nucleatum, Enterococcaceae or Campylobacter, Peptostreptococus, Enterococus faecalis, Escherichia coli, Shigella and Streptococcus gallolyticus, and a decrease in Faecalibacterium, Blautia, Clostridium, Bifidobacterium and Roseburia [19]. These changes might produce enrichment in pro-inflammatory opportunistic pathogens and a decrease in butyrate-producing bacteria, which may lead to an imbalance in intestinal homeostasis (dysbiosis) that could ultimately lead to tumor formation [11,20,21]. Ahn et al. described a decrease in bacterial diversity in fecal samples of CRC patients, with an increase in Fusobacterium nucleatum and Porphyromonas and a decrease in Gram-positive fiber-fermenting Clostridia [22]. Moreover, it has been shown that patients with colorectal tumours at an early stage (advanced adenoma) have a different 
microbiota composition compared with those with advanced stage tumours (definitive CRC) [19,23], suggesting that gut microbiota could participate in tumor progression.

Tjalsma et al. proposed a bacterial driver-passenger model for microbial involvement in the development of CRC, in which colonic mucosa contains bacterial species that differ in their temporal associations with developing tumours [24]. In this regard, early signs of dysbiosis in adenoma and an increased abundance of $F$. nucleatum were associated to a higher expression of pro-inflammatory cytokines in colonic tissue from CRC patients [25-27].

In mouse models of genetically predisposed CRC, it has been demonstrated that microbiota can elicit protumorigenic responses. For instance, $\mathrm{Li}$ et al. described the role of gut microbiota in the acceleration of tumor growth in APC $\left(\mathrm{Min} /{ }^{+}\right)$mice by triggering the c-Jun/JNK and STAT3 signaling pathways in combination with anemia [28]. On the other hand, it has been shown that in IL-10 deficient mice, an increased microbiota-specific Th1 response exacerbated colitis, resulting in adenocarcinoma formation [29]. In germ-free mice the transfer of stool from patients with CRC enhanced intestinal cell proliferation, suggesting a promotive effect of microbiota on tumour formation [30-32].

Nevertheless, the gut microbiome is not limited only to bacteria but also includes viruses and fungal species. Many studies have reported a higher viral DNA load in tumors in comparison to normal noncancerous tissue. A number of studies have aimed to assess the potential contribution of viral infections, such as infections with human papillomaviruses, human polyomaviruses and human herpesviruses, to the risk of CRC [33,34].

Community-based viral shotgun NGS techniques have revealed alterations in the colon virome diversity in CRC patients. In particular CRC cohorts displayed a higher viral diversity in CRC cohorts, with enrichment in members of the genera Orthobunyavirus, Inovirus and Tunalikevirus. Remarkably, the last two virus genera are known to infect Gram-negative bacterial hosts, including bft-positive enterotoxigenic Bacteroides fragilis, Fusobacterium nucleatum, and pks-positive genotoxic Escherichia coli, which are implicated in CRC development. The fecal virome profile has been shown to be able to predict CRC status and segregate individuals at early and late stages of CRC [35]. By contrast, another study performed by Hannigan et al. did not find virome community differences in alpha diversity (richness and Shannon diversity) and beta diversity (Bray-Curtis dissimilarity) between healthy and cancerous states, although they detected strong associations between the colon virus community composition and CRC. The identified viruses were lysogenic bacteriophages belonging to the Siphoviridae and Myoviridae taxa, which can alter the composition of gut bacterial communities [36]. These authors propose a theory on how bacteriophage-bacterium dynamics may promote a novel colonization niche for cancer-associated bacteria. Thus bacteriophages could alter bacterial populations in the colon by promoting bacterial lysis, which would allow the production of biofilms by the opportunistic species anchored to the epithelium. This would favor the penetration of oncogenic bacteria in the intestinal lumen, triggering the inflammatory immune response and promoting the transformation of tumor cells [36].

Furthermore, phage therapies that exploit the co-existence of specific bacteria within cancerous tumors to induce a specific anti-tumor immune response could be used in the treatment of CRC. In fact, Zheng et al. developed a phage-guided biotic-abiotic hybrid nanosystem that could increase the chemotherapeutic potency of irinotecan against CRC cells, selectively killing the F. nucleatum population and allowing the butyrate-producing bacteria to increase their abundance at the same time [37].

On the other hand, apart from the virome, metagenome of the fungal microbiota has also been studied in CRC. The fungal genera Phoma and Candida have been detected in higher quantities in colorectal adenoma biopsies, implicating altered host-associated fungal populations in the development of CRC [38]. In another study, a fungal dysbiosis in CRC patients have been described, with enrichment in the Basidiomycota/Ascomycota ratio and the class Malasseziomycetes in CRC patients when compared with healthy controls. On the contrary, in cancer patients a decrease in the relative abundance of Saccharomyces cerevisiae, yeast known for its anti-inflammatory and regulatory properties 
of the immune system, was observed, which could make it a potential therapeutic route. Ecological analysis also revealed a higher number of co-occurring fungal intra-kingdom correlations, and more co-exclusive correlations between fungi and bacteria in CRC compared with healthy controls [39].

Similarly, Gao et al. observed a fungal dysbiosis in colon polyps and CRC, with an increase in the Ascomycota/Basidiomycota ratio and in the opportunistic fungi Trichosporon and Malassezia, which might favor the progression of CRC. Subsequent analysis showed a lower diversity and significant mycobiota alteration in early-stage tumors [40].

All these studies revealed that CRC is not only characterized by a dysbalance in the composition of gut bacteria but also by a disruption of the gut virome and mycobiome homeostasis.

\subsection{Gut Microbiota Dysbiosis, Inflammation and CRC}

Chronic inflammation has been proposed to be involved in the promotion of cancer. Thus, it is estimated that up to $20 \%$ of all tumours are preceded by chronic inflammation [41]. During carcinogenesis, inflammatory cytokines and chemokines produced by cancer cells attract immature myeloid cells or pro-inflammatory helper $\mathrm{T}$ cells. This pro-tumorigenic microenvironment is characterized by the synthesis of growth and angiogenic factors and tissue remodelling enzymes, and the suppression of antitumor T-cell responses [42], favouring tumour progression. Gut microbiota dysbiosis and increased intestinal permeability are highly associated to colon inflammation, which could be a key factor for the initiation and/or progression of CRC [43]. Thus, when intestinal permeability is increased, the lipopolysaccharides of the outer membranes of some types of bacteria penetrate the host organism, which induces the immune system to secrete cytokines and start a cascade of reactions that ultimately leads to inflammation. Local inflammation contributes to tumor progression through protumorigenic cytokines and chemokines that act as growth factors and promote angiogenesis [42]. In mouse models it has been recently demonstrated that the development of polyps was associated with defects in the colon barrier integrity, bacterial invasion, and an increased expression of several inflammatory factors such as IL-17, Cxcl2, Tnf- $\alpha$, and IL-1. Moreover, alterations in the intestinal barrier allowed microbes to induce local inflammation, promoting polyp formation and cancer development in mice [44]. Hu et al. demonstrated that aberrant inflammasome-induced microbiota plays a critical role in CRC development, where mice deficient in the NOD-like receptor family pyrin domain containing 6 (NLRP6) inflammasome exhibited enhanced inflammation-induced CRC formation [45].

\subsection{Pathogenic Bacteria and CRC}

In addition to a shift in the microbiota composition, pathogenic bacterial species may also have a role in the development of CRC. There are different pathogenic microbes associated to the promotion of CRC, including several Bacteroides species (B. vulgatus and B. stercoris), Bifidobacterium species (B. longun and B. angulatum), Eubacterium species (E. rectale 1 and 2, E. elignes 1 and 2, and E. cylindroides), Ruminococus species (R. torques, R. albus, and R. gnavus), Streptococo hansenii, Fusobacterium prausnitzi, and Peptoestreptococo productus 1 [46]. All these microbes may drive CRC tumorigenesis by inducing proliferation of the epithelial cells, producing damage in the epithelial barrier, and causing inflammation. In addition, different toxins may damage DNA inducing a protumorigenic effect. For instance, Bacteroides fragilis toxin is known to activate Wnt and NF-kB signaling pathways and enhance epithelial release of pro-inflammatory molecules [47,48], E. coli toxin (colibactin toxin) causes DNA crosslinks and double strand DNA breaks [49], and Salmonella protein AvrA has recently been shown to induce $\beta$-catenin signaling and enhance colonic tumorigenesis by activating STAT3 pathway in a colon cancer mouse model [48]. Similarly, F. nucleatum has emerged as a potential candidate for CRC predisposition, because of its ability to bind to E-cadherin on the surface of colon cells through FadA adhesion, leading to the activation of Wnt/B-catenin signaling and the production of an inflammatory and oncogenic response [50]. Fap2, another adhesin from F. nucleatum, is able to bind to the inhibitory immune receptor TIGIT (T cell immune receptor with Ig and ITIM domains) and alter the function of natural killer cells and tumor infiltrating lymphocytes [51]. 
F. nucleatum has also been associated with resistance to the CRC chemotherapy agent oxaliplatin by inducing authophagy via Toll-like receptor 4 [51].

\section{Gut Microbiota-Derived Metabolites and CRC}

The gut microbiota produces different metabolites after anaerobic fermentation of exogenous undigested dietary components. These metabolites interact with the epithelial cells of the mucosal interface, influencing immune responses and the potential development of different diseases. The gut microbiota derived metabolites with pro-carcinogenic effects include products of protein fermentation such as polyamines [52]. Remarkably, a recent metagenomic analysis reported that the CRC-associated microbiome showed an association with alterations in polyamine metabolism [53], indicating that these metabolites could be particularly important in CRC development and progression. On the other hand, CRC has been associated to alterations in the metabolism of SCFAs [8,9], which have been shown to exhibit potential anti-carcinogenic effects in cellular and animal models of colon cancer.

\subsection{Gut Microbiota-Derived Polyamines and CRC}

Polyamines are aliphatic amines essential for normal cell growth. It is widely accepted that polyamine metabolism is frequently dysregulated in cancer, including CRC [54,55]. In colon cancer, ornithine decarboxylase (ODC), the key enzyme of the polyamine biosynthetic pathway, is expressed at higher levels in tumor tissue than in adjacent normal mucosa [56,57], suggesting that increased polyamine production could be involved in the tumorigenesis of CRC. The restriction of polyamine availability by alpha-difluoromethylornithine (DFMO) treatment, a chemical inhibitor of ODC, in combination with non-steroidal anti-inflammatory drugs has been shown to exhibit promising effects as therapeutic option for colorectal adenoma incidence [58,59]. A limitation of the monotherapy with DFMO, however, is that tumor cells can replace endogenously synthetized polyamines by taking extracellular polyamines from the colon lumen. This is particularly important in the case of CRC, which is surrounded by intestinal bacteria that are able to produce high levels of polyamines $[60,61]$. Remarkably, a recent metagenomic analysis has established that the CRC-associated microbiome showed an association with the conversion of amino acids to polyamines (e.g., L-arginine and L-ornithine degradation to putrescine) [53]. In mice, the administration of antibiotics enhanced the cytostatic effect of DFMO on tumor cells [62,63], suggesting that reduction of bacterial polyamine biosynthesis together with the inhibition of the polyamine biosynthesis route could be considered as an anti-tumoral strategy. Another promising strategy to limit the availability of polyamines in the tumor could be the combination of DFMO and the polyamine transport inhibitor AMXT 1501, which has shown to be effective in mouse models of neuroblastoma [64].

On the other hand, a metabolomics screen comparing paired colon cancer and normal tissue samples from patients with CRC revealed that bacteria biofilm formation, even in the normal colon tissue, was associated with increased colonic epithelial cell proliferation and host-enhanced polyamine metabolism [65]. In addition, bacteria-generated polyamines in biofilms may contribute to the inflammation and proliferation of colon cancer [58]. Following antibiotic treatment, resected colorectal cancer tissues harbored disrupted bacterial biofilms and lowered $\mathrm{N}^{1}, \mathrm{~N}^{12}$-diacetylspermine tissue concentrations compare to biofilm-negative colon cancer tissues, suggesting that gut microbes can induce an increase of host generated $\mathrm{N}^{1}, \mathrm{~N}^{12}$-diacetylspermine [66] (Figure 1). 


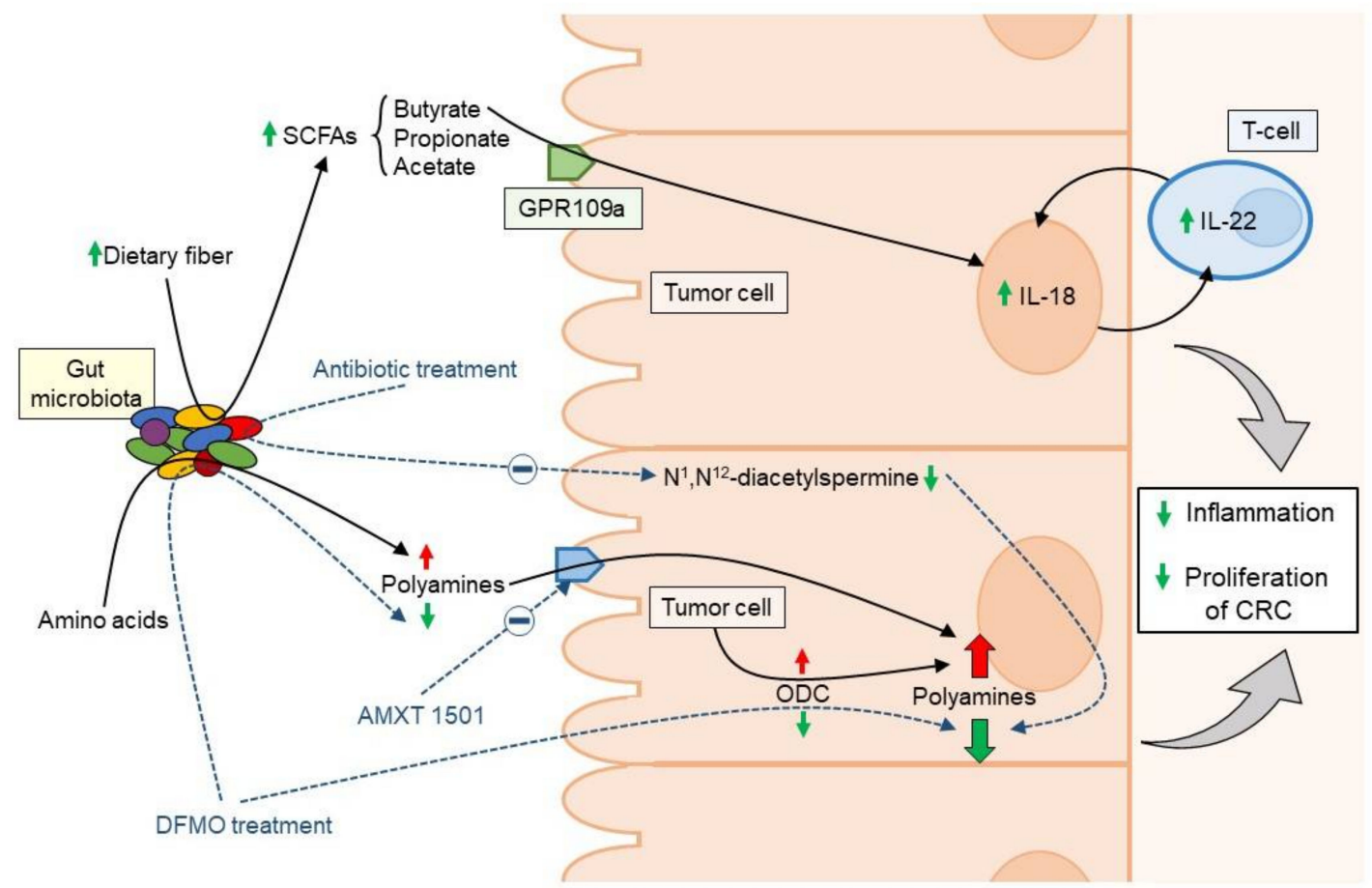

Figure 1. Mechanisms of action of polyamines and SCFAs (microbiota-derived metabolites) in the inflammation and cellular proliferation of colon cancer cells. SCFAs: short-chain fatty acids; ODC: ornitina descarboxilasa; DFMO: alpha-difluoromethylornithine; AMXT 1501: polyamine transport inhibitor; GPR109a: G-protein-coupled receptors; IL: interleukin.

\subsection{Short Chain Fatty Acid Metabolism and CRC}

SCFAs, especially butyrate, propionate and acetate, are products of the fermentation of dietary fiber by anaerobic gut microbiota with an essential role in the health of colonic mucosa through the modulation of the local immune response and the protection of the intestinal barrier. Recent studies have reported lower levels of butyrate-producing bacteria in CRC patients [18,67]. In addition, metabolomic analyses have described significant perturbations of SCFA metabolism in CRC compared to adjacent mucosa [68]. Butyrate has been shown to be able to induce IL-18 production in intestinal epithelial cells by activating GPR109a receptor, which stimulates the mucosal tissue repair through the regulation of the production and availability of IL-22 [69]. Remarkably, in mice the absence of IL-18 has been associated with gut microbiota dysbiosis, alterations of the inflammatory response, and a dysregulation of the homeostatic and mucosal repair [70,71], resulting in increased susceptibility to carcinogenesis. In fact, some experiments with mice that are unable to respond to IL-18 have shown a high incidence of intestinal dysbiosis and elevated susceptibility of chemically induced CRC carcinogenesis $[69,72,73]$. In addition, butyrate can induce the expansion of $\mathrm{T}$ reg lymphocytes to regulate the local immune response and suppressing colonic inflammation and carcinogenesis [74] (Figure 1).

\section{Antibiotic-Microbiome Link and CRC Risk}

The use of antibiotics generally has broad effects on the gut microbiota and indirectly affects CRC progression. The suppression of microbiota by antibiotics has been related to a decrease in crypt height and heme-induced colorectal carcinogenesis in rats [75]. Dick et al. described in a nested case-control study that the use of antibiotics with both anti-anaerobic or anti-aerobic activity (such as penicillins and quinolones) was associated with a dose-dependent increased risk of CRC development [76]. Interestingly, another nested case-control study in UK has shown that bacterial or fungal outgrowth after multiple penicillin treatments slightly increases the risk of CRC development [77]. ZacKular et al. 
demonstrated that manipulation of the gut microbiota with different antibiotic cocktails during the onset of inflammation can significantly decrease tumorigenesis in mice [78]. Bullman et al. showed that the treatment with metronidazole of mice xenografted with CRC decreased both the load of F. nucleatum and the growth of the tumor [79]. In an azoxymethane (AOM)/dextran sodium sulfate (DSS)-induced CRC murine model the alteration of gut microbiota using antibiotics attenuated colon tumorigenesis, but only when gut microbial changes were maintained throughout the entire period of inflammation [80]. Recently, Ma et al. described that the alterations of gut microbiota after antibiotic use could contribute to the long-term dysregulation of host immune homeostasis and affect CRC pathogenesis [81]. In another meta-analysis, Wang et al. suggested that a higher number of antibiotic prescriptions were associated with a higher risk of CRC. By contrast, they described that the risk of rectal cancer was inversely associated with antibiotic exposure, possibly due to the differences in the composition of gut microbiota between colon and rectum [82].

On the other hand, the use of antibiotics in early childhood has been associated with increased colonic adenoma formation (a precursor lesion to CRC) in later life, suggesting that a dysbiotic microbiota is acquired and hold over a longer period of time [83-85]. In a recent study based on the Clinical Practice Research Datalink (CPRD), the use of oral antibiotics with anti-anaerobic activity has been associated with increased CRC risk in a dose-dependent fashion in the UK population, although the effects differed depending on the anatomical location, being greatest in the proximal colon [86]. In this regard, a systematic review and meta-analysis of observational studies was performed to assess whether the use of antibiotics was associated with the development of pre-cancerous or cancerous lesions in adults [87]. In this review the authors only found a weak association between cumulative antibiotic use and risk of CRC. These results could be explained by confounding factors within the studies, such as heterogeneity in how antibiotic exposure was registered, the variability in the route and setting of antibiotic exposure among studies, the relatively short time between antibiotic exposure and the development of CRC in the majority of studies, and that none of the included studies tried to differentiate microbiome-associated events between initiation of CRC as polyp prevalence and progression through more advanced stages [87].

Another recent work, Armstrong et al. showed that patients prescribed antibiotics in up to 15 years preceding diagnosis were associated with a higher risk of CRC [88].

On the other hand, the use of antibiotics often leads to dysbiosis, facilitating the acquisition of drug resistance. In this context, Yuan et al. found that antibiotic treatment-induced gut microbiota dysbiosis decreased the therapeutic efficacy of 5-fluorouracil (5-FU) for tumor treatment [89]. Remarkably, antibiotic use before (but not following) the start of 5FU-based chemotherapy has been associated with worse progression-free and overall survival among patients with metastatic colorectal cancer [90].

In addition, the disruption of microbiota in MC38 colon carcinoma-grafted mice with a broad-spectrum antibiotics impaired tumor response to anti-CTLA4 immunotherapies [91]. Nevertheless, the efficacy of anti-CTLA4 treatment in antibiotic-treated MC38-grafted mice could be rescued by colonizing mice with $B$. fragilis, immunizing with low dose of a recombinant BFT-2 enterotoxin (a major virulence factor of $B$. fragilis), or performing adoptive transfer with $B$. fragilis-specific T cells [92].

\section{Dietary Mediators of CRC Carcinogenesis}

\subsection{Dietary Fiber}

Dietary fiber has been shown to beneficially affect metabolic activities in the gastrointestinal tract $[93,94]$. In the observational EPIC study, Bingham et al. found that dietary fiber was inversely associated with the incidence of large bowel cancer, although no significant differences were observed between various food sources of dietary fiber intake on the protection against CRC [95]. In another large prospective cohort study, the protective effect of whole-grain consumption was associated with a slight reduction in the risk of developing CRC [96]. In a prospective case-control study nested within 
seven UK cohort studies using food intake questionnaires, both the intake of absolute fiber as well as the fiber intake density were inversely associated with the risk of colorectal and colon cancers in both age-adjusted models and multivariable models adjusted for age, anthropomorphic and socioeconomic factors, dietary intake of folate, alcohol consumption, and energy intake [97]. The protective effect of dietary fiber remained evident in the 11-year follow-up of the EPIC study, being the total dietary fiber intake still inversely associated with colorectal cancer [98]. Similarly, a prospective study in the Scandinavian HELGA cohort showed that the intake of dietary fiber (especially from cereals) was associated with a reduction in the incidence of CRC [99]. Moreover, a higher intake of dietary fiber and whole grains after CRC diagnosis has been associated with better survival rates [100]

Moen et al. compared the effects of several dietary interventions (inulin, cellulose or brewers spent grain) in AOM -treated A/J Min/+ mice, finding that the mice fed with inulin displayed lower incidence of colonic tumorigenesis and a distinct cecal microbiota profile associated with low colonic tumor load [101].

On the other hand, Mehta et al. found that diets rich in whole grains and dietary fiber were associated with a lower risk of developing F. nucleatum-positive colorectal cancer but not F. nucleatum-negative CRC, supporting a potential role for intestinal microbiota in mediating the association between diet and the development of colorectal neoplasms [102].

More recently, the fermentation of soluble fibers such as lignan and $\beta$-glucan to SCFAs by gut microbiota also plays a critical role in cancer prevention. The ingestion of dietary fiber has been associated with the presence of fecal butyrate-producing bacteria $[103,104]$. Remarkably, lower fecal SCFA levels as a consequence of a lower dietary fiber intake and lower prevalence of Clostridium, Roseburia, and Eubacterium spp. were found in CRC risk subjects compared to healthy individuals [104]. In agreement, a dietary intervention consisting in a higher intake of dietary fibers in African Americans increased saccharolytic fermentation and butyrogenesis, and suppressed secondary bile acid synthesis, resulting in the reduction of biomarkers of colon cancer risk [105]. In line with this work, another study using a gnotobiotic mouse models demonstrated that dietary fiber protected against colorectal tumorigenesis in a microbiota- and butyrate-dependent manner via inhibition of histone deacetylase activity [106]. In addition, high fiber diets given to mouse models of polyposis also produced a significant increase of SCFA-producing bacteria and ameliorated polyposis [107].

The possible mechanism that could explain the role of dietary fiber in CRC prevention could be that fiber reduces concentrations of intestinal carcinogens due to the reduction of intestinal transit time and increased faecal bulk, which would lessen the potential for faecal mutagens to interact with the colon mucosa [83]. In addition, the increase bacterial fermentation of resistant starch to SCFAs (especially butyrate) has been shown to lower fecal $\mathrm{pH}$ in the colon, and this $\mathrm{pH}$ reduction can inhibit pathogenic organism proliferation and DNA damage induction, and enhance apoptosis and prevent proliferation of cancer cells [108-110]. On the other hand, it has been decribed that long-term fiber dominant diet may increase the density of Firmicutes, which may have immune modulatory and anti-inflammatory effects in the host [111,112] (Figure 1).

Altogether, a higher fiber intake could not only prevent the disturbances in the community structure and function of the gut microbiota, but could also stimulate the production of bacterial metabolites with anti-CRC activity such as butyrate (see below). Moreover, the intake of fiber after CRC diagnosis has been associated with better survival rates. Nevertheless, more clinical and preclinical studies are necessary to establish the most appropriate conditions (dose and duration) of these dietary interventions involving high-fiber intake to prevent CRC (Table 1).

\subsection{Diets Rich in Polyunsaturated Fatty Acids}

Diverse studies have recently defined an impact of dietary omega-3 polyunsaturated fatty acids (PUFAs) on the gut microbiota [113]. In particular, the supplementation of PUFAs has been associated with a decrease in Faecalibacterium and an increase of Bacteroidetes and butyrate-producing bacteria [114]. In addition, PUFAs are able to reduce intestinal microbial dysbiosis by increasing the proportions 
of beneficial bacteria and decreasing the proportions of pathogenic bacteria in the gastrointestinal tract [115].

PUFAs have been extensively studied due to their role in their protective effect from CRC carcinogenesis, mainly through mechanisms that regulate differentiation and apoptosis of the colonocytes [116-119]. For instance, in C57BL/6J mice bearing azoxymethane-dextran sulfate sodium-induced CRC, the relative abundance in the gut of beneficial bacteria such as Lactobacillus increased after eicosapentaenoic acid treatment, in parallel with a reduction in the size of colorectal tumors, a decrease in the number of proliferating cells, and an increase of apoptotic cells within the tumors [120]. These PUFAs could also alter the cell cycle components, act on the immune system and modulate CRC-related genes expression [121]. The protective role of PUFAs in colorectal carcinogenesis prevention may also relate to the decreased risk of microsatellite instability (MSI) and the enhancement of DNA repair systems mismatch pathways [122].

On the other hand, several randomized control trials have reported that PUFAs are often subjected to peroxidation, process by which free radicals are frequently generated [123]. In addition, Yang et al. found that the PUFA composition is different between normal and cancerous tissues in the same CRC patient, suggesting that the metabolism of PUFAs might play a significant role in the evolution of inflammation driven tumorigenesis in the CRC [124].

In rats exposed to azoxymethane, a potent carcinogen used to induce colon cancer in animal models, the consumption of dietary fish oil (which is rich in omega-3 PUFAs) led to a lower rate of CRC adenocarcinoma incidence [125]. Song et al. reported that high marine $\omega-3$ PUFA intake after CRC diagnosis is associated with a lower risk of CRC-specific mortality, indicating that an elevated consumption of marine $\omega-3$ PUFAs after diagnosis may confer additional benefits to patients with CRC [126]. Furthermore, other investigations have demonstrated that in animals with carcinogen-induced CRC tumors fed with a diet of fish oil plus pectin had increased colonocyte apoptosis compared with those fed with corn oil cellulose as control diet [127]. Moreover, it has been recently shown that docosahexaenoic acid in combination with butyrate enhances mitochondrial lipid oxidation and reduces mitochondrial membrane potential, contributing to the induction of apoptosis in colonocytes $[109,128]$. A recent clinical trial has shown a CRC incidence reduction of $22 \%$ among pesco-vegetarian subjects compared with non-vegetarian individuals [129]. Finally, a very recent study performed by Aglago et al. analyzed the association between fish consumption and dietary and circulating levels of PUFAs with CRC incidence using data from the EPIC cohort. They found that the regular intake of fish at recommended levels was associated with a lower risk of CRC, possibly through the exposure to high PUFA content [130].

Several in vivo studies have described that PUFAs can reduce 5-FU-related toxicity and potentiate 5-FU anti-cancer activity though the reduction of tumor burden and DNA damage and the increase of apoptosis [131-133]. A recently study in rat models showed that combining PUFAs with 5-FU and irinotecan could help restore lipid stocks, thus potentially limiting 5-FU-associated side effects [134]. Cai et al. showed that PUFAs have the potential to radio-sensitise HT29 colon cancer cells, possible due to an increase in lipid peroxidation products within the cells [135]. Granci et al. reported an increase in apoptosis in colon cancer cells when combining 5-FU, oxaliplatin, and irinotecan with a fish oil emulsion with PUFAs [136] (Figure 2).

A recent double-blind, randomized, placebo-controlled trial investigated the effect of the combination treatment of PUFA and a probiotic supplement on the tolerability of capecitabine/oxaliplatin chemotherapy and on inflammatory markers in CRC patients, finding an improved overall quality of life and reduced chemotherapy-induced symptoms such as diarrhea and fatigue in these study subjects [137].

Then, PUFAs have a protective effect from CRC carcinogenesis and in combination with chemotherapeutic agents could be an effective approach to the treatment of CRC patients (Table 1). 


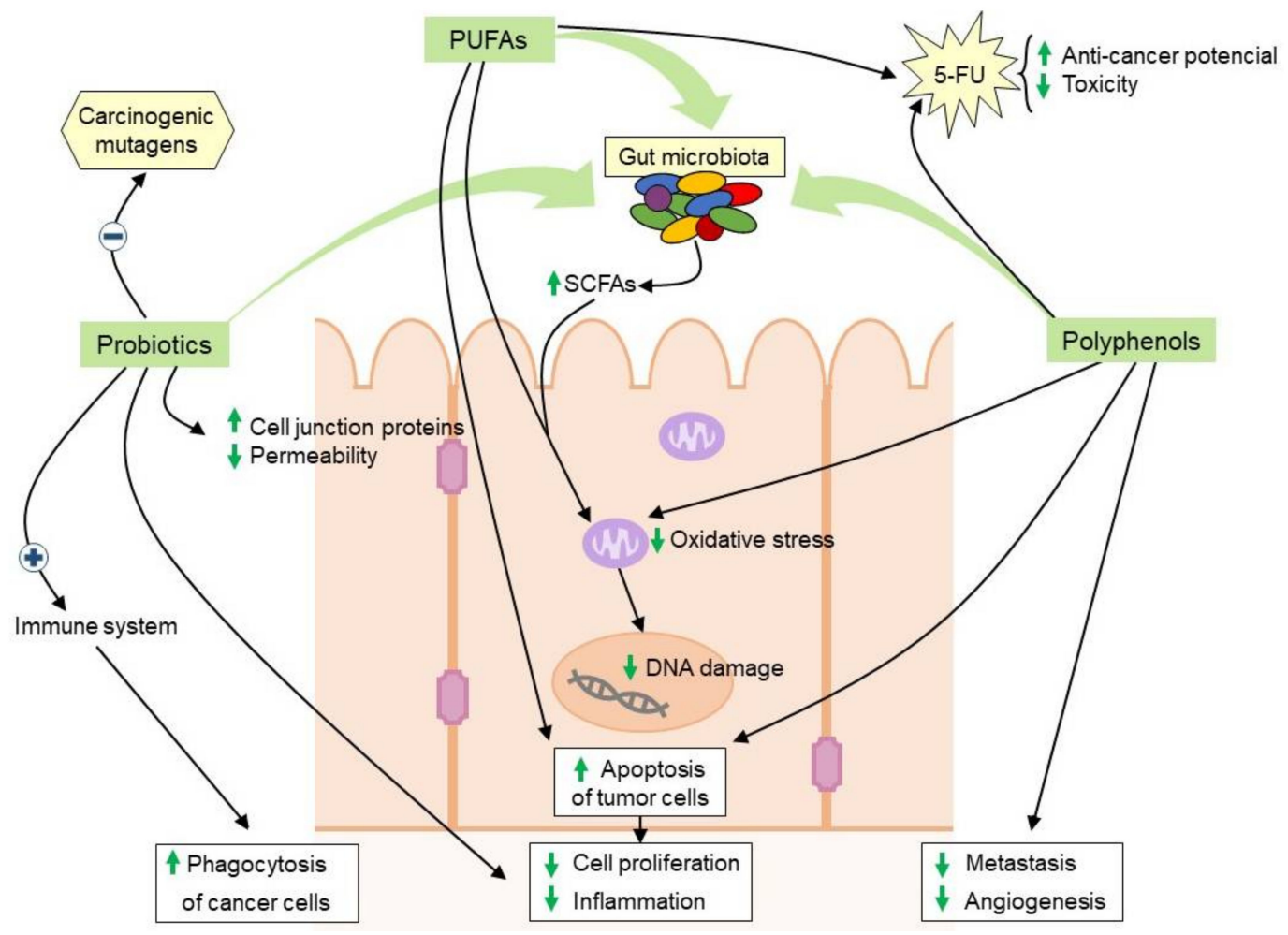

Figure 2. Beneficial effects of dietary supplementation with PUFAs, polyphenols and probiotics on the intestinal microbiota and colon cells for the reduction of CRC risk or to enhance the response to cancer therapy when are used as adjuvant to conventional treatment. PUFAs: omega-3 polyunsaturated fatty acids; 5-FU: 5-fluorouracil; SCFAs: short-chain fatty acids.

\subsection{Bioactive Polyphenols}

Most fruits and vegetables contain phytochemicals with anti-microbial and anti-inflammatory properties [138]. Phytochemicals are able to maintain the balance of the gut microbiota and exhibit anti-tumoral properties (e.g., decrease cell proliferation and stimulate apoptosis of cancer cells, inhibit angiogenesis and delay metastasis) [139]. Polyphenols are a structural class of phytochemicals with multiple phenolic units that are found at high concentrations in coffee, tea, wine, fruits, vegetables and whole grains $[140,141]$. Because polyphenols are poorly absorbed in the small intestine they usually tend to accumulate in the colon, where they can be hydrolyzed by the enzymatic activities of the gut microbial community into lower molecular-weight bioactive compounds before absorption [142-144]. Moreover, polyphenols present in the colon have been found to significantly alter the gut microbiota, particularly by suppressing the growth of Clostridium and Bacteroides species [145-147].

On the other hand, red wine polyphenols have been linked to CRC prevention by their capacity of inhibiting the growth of pathogenic bacterial species such as F. nucleatum and P. gingivalis [148], as well as the adhesion to oral cells [149].

Several studies have described the effects of certain polyphenolic compounds in CRC prevention and treatment both in vivo and in vitro. Quercetin, a flavonol present at high concentrations in certain vegetables and fruits such as onions or apples, has been shown to exert some anticancer effects in colon cancer cells, mainly by inhibiting cell proliferation and inducing apoptosis [150]. Anthocyanin-rich tropical fruits such as Cocoplum (Chrysobalanus icaco L.) have also demonstrated anti-inflammatory activity (through the reduction of TNF- $\alpha$, IL- $1 \beta$, IL-6, and NF-KB expression levels) and pro-oxidant effect in the human colorectal adenocarcinoma cell line HT29 [136,151]. In HCT116 colon cancer cells, the activity of apigenin was correlated with a blockage in cell cycle progression, induction of apoptosis and inhibition of autophagy [152]. The antitumor effects of several polyphenols present in high amounts in blueberries, red grapes and cocoa (such as anthocyanins and tannins) have been related to 
their capability of inducing adaptive immune cells to target tumor cells in preclinical models [153-155]. In addition, the combination of curcumin and resveratrol has been shown to be highly effective in inhibiting the growth of colon cancer cell both in vitro and in vivo [156]. In some clinical studies, the intake of flavonols and flavan-3-ol monomers has been associated with a decreased risk in colorectal cancer [157]. However, the association between the regular intake of either total flavonoids or any flavonoid subclass and CRC risk and tumor subsites could not be corroborated in other human cohort studies $[158,159]$.

Emerging evidence suggests that the combination of conventional chemotherapy treatment for CRC with some natural dietary polyphenols can significantly enhance the chemotherapeutic effect. For instance, quercetin has been tested in vitro in combination with 5-FU in CO115 human colon carcinoma cells and HCT15 colorectal adenocarcinoma cells increasing apoptosis levels in CO115 cell line, in a synergistic manner, but as an additive effect in HCT15 cells [160]. Also, the combination of 5-FU against a colon adenocarcinoma cell line treatment with phenolic acid rich-extracts such as Gelam honey and ginger (Zingiber officinale) enhanced the anticancer activity of 5-FU [140,161]. On the other hand, Montrose et al. demonstrated in DSS-mice that the chemopreventive effect of black raspberries was mediated by the downregulation of the expression of pro-inflammatory cytokines (TNF- $\alpha$ and IL-1 $\beta$ ) and the decrease of COX-2 and plasma prostaglandin E2 levels [162]. On the other hand, the chemopreventive effect of curcumin through the reduction of colonic tumor burden due to the maintenance of a high microbial diversity was proven in IL-10-deficient mouse [163]. Moreover, curcumin is able to enhance chemosensitization to 5-FU-based chemotherapy by targeting cancer stem cell subpopulations that could be responsible for tumor relapse and resistance to conventional therapies [164]. The effect of 5-FU also increased in combination with resveratrol due to its chemosensitizing properties [165]. Moreover, resveratrol could be used to overcome drug resistance in combination with other chemotherapeutic drugs, due to its ability to downregulate multidrug resistant protein 1 by preventing the activation of NF- $\kappa B$ signalling and suppressing cAMP-responsive element transcriptional activity [166] (Figure 2).

These findings suggest that polyphenols and their derived microbial metabolites could be used as a complementary therapy not only for CRC prevention, but also in potentiating the efficacy of chemotherapy against CRC (Table 1).

\subsection{Probiotics}

Probiotics are live microorganisms that contribute to the health benefit of the patients and are able to inhibit CRC through different mechanisms (Figure 2). Several studies have suggested that regular consumption of probiotics may improve the diversity and richness profile of the intestinal microbiota, downregulate chronic inflammation, and reduce the production of carcinogenic compounds during intestinal dysbiosis $[167,168]$.

Hatakka et al. demonstrated that the consumption of certain strains of probiotic bacteria can reduce the activity of intestinal enzymes that can convert aromatic hydrocarbons and amines in active carcinogens and prevent colon cancer [169]. The peptidoglycan, polysaccharide and secreted glycoproteins on the surface of probiotic bacteria, combined with carcinogenic mutagens could be responsible for biotransformation aiming to detoxification [170].

On the other hand, probiotics can also regulate the immune system response through the activation of phagocytes to eliminate cancer cells in their early stages of development, contributing to the maintenance of the immune-vigilance state [171,172]. For instance, the probiotic strain Bifidobacterium animalis subsp. Lactis can produce mycosporin-like amino acids, which are able to modulate host immunity by regulating the proliferation and differentiation of intestinal epithelial cells, macrophages and lymphocytes and the production of cytokines [173]. Nevertheless, not all probiotics are able to regulate the immune system and to prevent the development of CRC. To induce immunostimulation on the host, both a dosage of around $10^{9} \mathrm{CFU} /$ day and an intestinal transit time between 48 and $72 \mathrm{~h}$ are necessary [168]. 
Probiotics are also known to stimulate the production of a variety of compounds that improve the intestinal barrier function. The perioperative administration of CRC patients with a probiotic consisting in a mixture of Lactobacillus plantarum, Lactobacillus acidophilus and Bifidobacterium Longum increased the expression of mucosal tight junction proteins, improved the integrity of gut mucosal barrier and reduced enteropathogenic bacteria, resulting in decreased infectious complications after colorectomy [174].

In one randomized, double-blind, placebo-controlled trial, patients with colon cancer and polypectomized patients, Rafter et al. demonstrated that oral treatment with a probiotic mixture of Lactobacillus rhamnosus and Bifidobacterium Breve was able to induce changes in gut microbiota, reduce several cancer biomarkers such as colorectal proliferation, and improve intestinal epithelial barrier permeability [175]. Interestingly, when the bacterial probiotic strains L. acidophilus NCFM and B. animalis subsp. lactis $\mathrm{Bl}-04$ were used in a prospective intervention study with CRC patients, it was observed that the patients with colon cancer that received probiotics had a unique profile of bacterial populations in their gut microbiota, which was mainly characterized by an increased abundance of butyrate-producing species in tumor, mucosa and fecal samples [176]. Other probiotic strains derived from Bifidobacterium have been shown to restore the equilibrium of the gut dysbiosis in patients with CRC [177].

The consumption of probiotics has been also associated with the induction of a proapoptotic activity in cancer cells of human CRC patients. Wan et al. found that the consumption of Lactobacillus Delbrueckii increased the expression of caspase-3, leading to apoptosis of human colon cancer cells [178]. Furthermore, Konishi et al. described that L. casei strain ATCC 334 produced ferrichrome, a molecule that inhibits the progression of colon cancer by inducing the apoptosis of cancer cells via c-Jun N-terminal kinase pathway [179].

In addition, several studies have described a relationship between gut microbiota and the efficacy and/or toxicity of both chemotherapies and immunotherapies $[180,181]$. Probiotics has been also shown to affect the response to immunotherapy by systemic priming and regulation of different myeloid-derived cell functions in the tumor microenvironment. Tumor-infiltrating myeloid cells appear to be primed by bacterial LPS through the TLR4 receptor for responsiveness to the TLR9 ligand CpG-ODN [181]. In this regard, Chang et al. described that L. casei variety rhamnosus (LCR35) attenuated 5-FU/oxaliplatin-induced intestinal mucositis in CRC-bearing mice [182]. Moreover, recent studies have described that the combination of PD-L1 inhibitors and oral therapy with bifidobacteria had a synergistic inhibitory effect on tumor growth compared with the effect of either intervention alone [183-185]. In CRC patients undergoing chemotherapy the supplementation with L. rhamnosus decreased the frequency of diarrhea and abdominal distress and avoided the dose reduction caused by intestinal toxicity compared to patients who received placebo [186].

Finally, probiotics have been studied in the setting of radiation therapy used in the treatment of CRC patients. Previous studies have demonstrated that intestinal bacteria can repair injuries and reduce the incidence and severity of diarrea and bowel movements induced by the radiation therapy [187].

Taken together, the probiotic interventions could be therapeutically used to target the gut dysbiosis frequently observed in CRC patients, due to their beneficial effects on the immune system and the intestinal barrier function, as well as, their antitumoral properties by releasing metabolites that are able to get rid of potential carcinogens. Moreover, the modification of the composition of CRC microbiome with probiotics might enhance the effectiveness to cancer chemotherapy and immunotherapies and the reduction of toxicity associated to radiation therapy. Noteworthy, not all probiotic strains showed anti-CRC effects and their beneficial impact depends on the bacterial strain, the dosage, the duration of intervention and the intestinal transit time. Further investigations are therefore necessary to clarify the action mechanism and the potential of probiotics in CRC prevention (Table 1). 
Table 1. Interactions between dietary mediators, gut microbiota and CRC.

\begin{tabular}{|c|c|c|c|c|}
\hline Study (Reference) & Dietary Mediator & Type of Study & Species & Most Relevant Results \\
\hline \multicolumn{5}{|l|}{ Dietary Fiber } \\
\hline Lattimer et al. 2010 [93]) & $\begin{array}{l}\text { Dietary Fiber (Arabinoxylan, Inulin, } \\
\beta \text {-glucan, Pectin, Bran, Cellulose, } \\
\text { Resistant Starch) }\end{array}$ & In vivo & Human & $\begin{array}{l}\uparrow \text { Excretion of bile acids, } \\
\uparrow \text { Production of fecal SCFAs } \\
\uparrow \text { Antioxidants } \\
\downarrow \text { Cancer prevalence }\end{array}$ \\
\hline Zeng et al. 2014 [94] & Dietary Fiber & In vivo & Human & $\begin{array}{l}\downarrow \text { Fecal } \mathrm{pH} \text { in the colon } \\
\uparrow \text { SCFA-producing gut bacteria } \\
\uparrow \text { Apoptosis of colon cancer cells } \\
\downarrow \text { Chronic inflammatory process and migration/ } \\
\text { invasion of colon cancer cells }\end{array}$ \\
\hline Deehan et al. 2020 [103] & Dietary Fiber & In vivo & Human & $\begin{array}{l}\text { Modulation of the colon microbiota } \\
\uparrow \text { Saccharolytic fermentation } \\
\uparrow \text { Production of fecal SCFAs }\end{array}$ \\
\hline Chen et al. 2013 [104] & Dietary Fiber & In vivo & Human & $\begin{array}{l}\uparrow \text { Production of SCFAs by healthy gut microbiota, } \\
\downarrow \text { Risk of advanced colorectal adenoma. }\end{array}$ \\
\hline $\begin{array}{l}\text { Burkitt et al. } 1993 \text { [108]; } \\
\text { Bergman et al. } 1990 \text { [109]; } \\
\text { Hamer et al. } 2008 \text { [110] }\end{array}$ & Dietary Fiber & In vivo & $\begin{array}{l}\text { Human/ } \\
\text { Mouse }\end{array}$ & $\begin{array}{l}\uparrow \text { Production of fecal SCFAs (especially butyrate) } \\
\downarrow \text { Fecal pH in the colon, } \\
\downarrow \text { Pathogenic organism proliferation } \\
\downarrow \text { DNA damage induction } \\
\uparrow \text { Apoptosis of colon cancer cells } \\
\downarrow \text { Proliferation of colon cancer cells. }\end{array}$ \\
\hline $\begin{array}{l}\text { Fung et al. } 2012 \text { [111]; } \\
\text { Neish et al. } 2009 \text { [112] }\end{array}$ & Long-term dietary fiber intake & In vivo & Human & $\begin{array}{l}\uparrow \text { Abundance of Firmicutes abundance } \\
\uparrow \text { Immune modulatory and anti-inflammatory } \\
\text { effects in the host }\end{array}$ \\
\hline Bingham et al. 2003 [95] & Dietary Fiber & In vivo & Human & $\begin{array}{l}\uparrow \text { Total dietary fiber intake } \\
\downarrow \text { Risk of CRC }\end{array}$ \\
\hline Schatzkin et al. 2007 [96] & Dietary Fiber (whole grains) & In vivo & Human & $\begin{array}{l}\uparrow \text { Whole grain food consumption } \\
\downarrow \text { Risk of CRC (modest) }\end{array}$ \\
\hline Dahm et al. 2010 [97] & Dietary Fiber & In vivo & Human & $\begin{array}{l}\uparrow \text { Fiber intake } \\
\downarrow \text { Risk of CRC }\end{array}$ \\
\hline Hansen et al. 2012 [99] & Dietary Fiber (cereals) & In vivo & Human & $\begin{array}{l}\uparrow \text { Total dietary fiber } \\
\downarrow \text { Risk of CRC }\end{array}$ \\
\hline Song M et al. 2018 [100] & Dietary Fiber (whole grains) & In vivo & Human & $\uparrow$ Survival rates of non-metastatic CRC \\
\hline
\end{tabular}


Table 1. Cont.

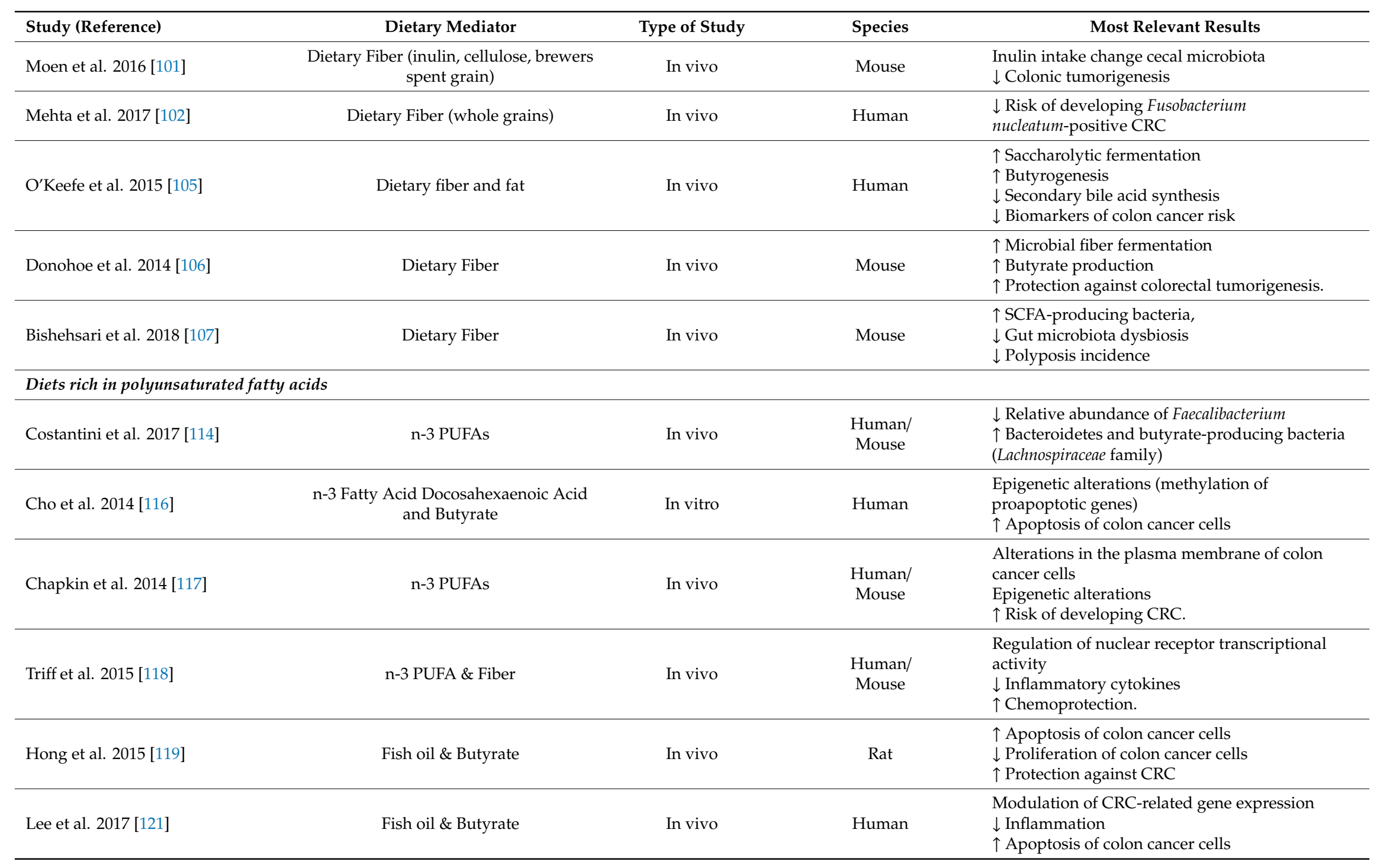


Table 1. Cont

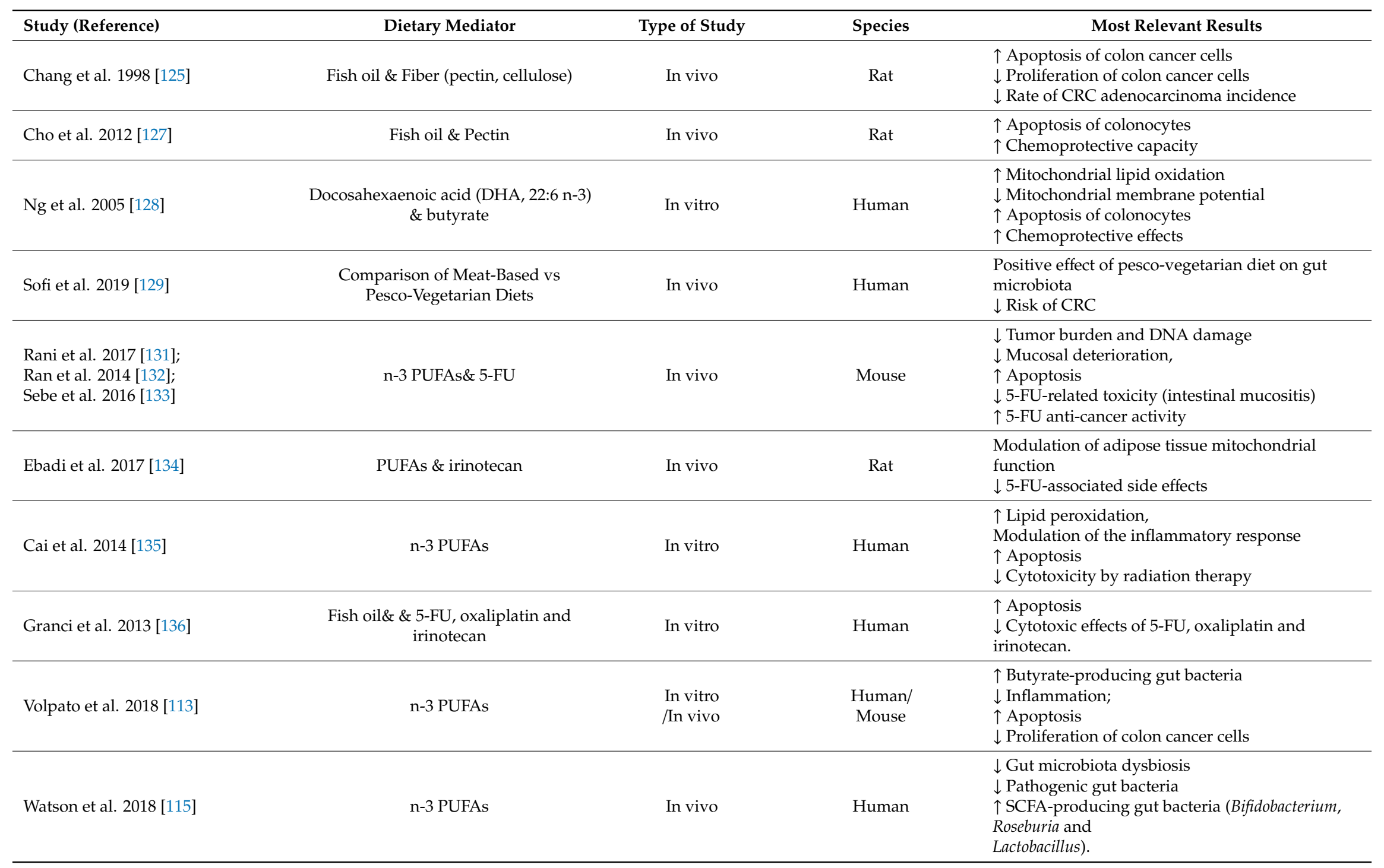


Table 1. Cont.

\begin{tabular}{|c|c|c|c|c|}
\hline Study (Reference) & Dietary Mediator & Type of Study & Species & Most Relevant Results \\
\hline Piazzi et al. 2014 [120] & Eicosapentaenoic Acid & In vivo & Mouse & $\begin{array}{l}\uparrow \text { Lactobacillus species in the gut microbiota } \\
\downarrow \text { Size of CRC tumors } \\
\downarrow \text { Proliferation colon cancer cells } \\
\uparrow \text { Apoptosis colon cancer cells }\end{array}$ \\
\hline Song et al. 2015 [122] & n-3 PUFAs & In vivo & Human & $\begin{array}{l}\downarrow \text { Risk of microsatellite instability } \\
\uparrow \text { DNA repair systems mismatch pathways }\end{array}$ \\
\hline Yang et al. 2015 [124] & n-3 PUFAs & In vivo & Human & $\begin{array}{l}\text { Different PUFA composition between normal and } \\
\text { cancerous tissues } \\
\downarrow \text { Inflammation in CRC tumorigenesis. }\end{array}$ \\
\hline Song et al. 2017 [126] & Marine $\omega-3$ PUFAs & In vivo & Human & $\begin{array}{l}\uparrow \text { Intake of marine } \omega \text { - } 3 \text { after CRC diagnosis } \\
\downarrow \text { Risk of CRC-specific mortality. }\end{array}$ \\
\hline Aglago et al. 2020 [130] & n-3 PUFAs & In vivo & Human & $\begin{array}{l}\text { Regular intake of fish at recommended levels } \\
\downarrow \text { Risk of CRC }\end{array}$ \\
\hline Golkhalkhali et al. 2018 [137] & n-3 PUFAs \& probiotic supplement & In vivo & Human & $\begin{array}{l}\uparrow \text { Tolerability of capecitabine/oxaliplatin } \\
\text { chemotherapy } \\
\uparrow \text { Quality of life markers } \\
\downarrow \text { Chemotherapy-induced symptoms (diarrhea and } \\
\text { fatigue) }\end{array}$ \\
\hline Mileo et al. 2019 [139] & Polyphenols & In vivo/In vitro & $\begin{array}{l}\text { Human/ } \\
\text { Mouse }\end{array}$ & $\begin{array}{l}\uparrow \text { Gut microbiota balance } \\
\downarrow \text { Proliferation of colon cancer cells } \\
\uparrow \text { Apoptosis of colon cancer cells }\end{array}$ \\
\hline Miene et al. 2009 [143] & Polyphenols (Apple) & In vitro & Human & $\begin{array}{l}\text { Polyphenols are metabolized by colonic microbiota } \\
\downarrow \text { DNA damage induced by oxidative stress in } \\
\text { colonic adenoma cells }\end{array}$ \\
\hline Gibellini et al. 2011 [150] & Quercetin & In vivo & Human & $\begin{array}{l}\downarrow \text { Proliferation of colon cancer cells } \\
\uparrow \text { Apoptosis of colon cancer cells }\end{array}$ \\
\hline Venancio et al. 2017 [151] & Polyphenols (Cocoplum) & In vitro & Human & Anti-inflammatory activity and pro-oxidant effects \\
\hline Lee Y et al. 2014 [152] & Apigenin & In vitro & Human & $\begin{array}{l}\downarrow \text { Cell cycle progression } \\
\downarrow \text { Autophagy } \\
\uparrow \text { Apoptosis }\end{array}$ \\
\hline Xavier et al. 2011 [160] & Polyphenols & In vitro & Human & $\uparrow$ Apoptosis (in combination with 5-FU) \\
\hline Hakim et al. 2014 [161] & Gelam Honey and Ginger & In vitro & Human & $\uparrow$ Anticancer activity of 5-FU \\
\hline
\end{tabular}


Table 1. Cont.

\begin{tabular}{|c|c|c|c|c|}
\hline Study (Reference) & Dietary Mediator & Type of Study & Species & Most Relevant Results \\
\hline Montrose et al. 2015 [162] & $\begin{array}{l}\text { Black Raspberry (Anthocyanins, simple } \\
\text { phenols, ellagic acid and quercetin) }\end{array}$ & In vivo & Mouse & $\begin{array}{l}\downarrow \text { Expression of proinflammatory cytokines } \\
\text { (TNF- } \alpha \text { and IL-1 } \beta \text { ) } \\
\downarrow \text { Plasma levels of COX- } 2 \text { and prostaglandin E2 } \\
\uparrow \text { Chemopreventive effect }\end{array}$ \\
\hline McFadden et al. 2015 [163] & Curcumin & In vivo & Mouse & $\begin{array}{l}\uparrow \text { Microbial diversity } \\
\downarrow \text { Colonic tumor burden } \\
\uparrow \text { Chemopreventive effect }\end{array}$ \\
\hline Shakibaei et al. 2014 [164] & Curcumin & In vitro & Human & $\uparrow$ Chemosensitization to 5-FU treatment \\
\hline Wang et al. 2015 [166] & Resveratrol & In vitro & Human & $\begin{array}{l}\downarrow \text { Drug resistance (down-regulation of multi-drug } \\
\text { resistant protein } 1 \text { ), } \\
\downarrow \text { Activation of NF-kB signaling } \\
\downarrow \text { Transcriptional activity of the cAMP-sensitive } \\
\text { element }\end{array}$ \\
\hline Paul et al. 2010 [153] & Pterostilbene (Blueberries) & In vivo & Rat & $\begin{array}{l}\downarrow \text { Colon tumorigenesis by regulating the } \\
\text { Wnt/b-catenin-signaling pathway } \\
\downarrow \text { Inflammatory responses. }\end{array}$ \\
\hline Cui et al. 2010 [154] & Resveratrol & In vivo & Mouse & $\downarrow$ Colitis-driven colon cancer incidence \\
\hline Rodríguez-Ramiro et al. 2013 [155] & Polyphenols (Cocoa) & In vivo & Rat & $\begin{array}{l}\text { Anti-inflammatory effect on the colonic tissue } \\
\text { Chemoprevention in the early stages }\end{array}$ \\
\hline $\begin{array}{l}\text { Simons et al. } \\
2009 \text { [157] }\end{array}$ & Flavonol, Flavone and Catechin & In vivo & Human & $\downarrow$ Risk of CRC \\
\hline Zamora-Ros et al. 2017 [158] & Flavonoid & In vivo & Human & $\begin{array}{l}\text { No association between regular dietary intake of } \\
\text { flavonoids and CRC risk }\end{array}$ \\
\hline $\begin{array}{l}\text { Sánchez et al. } 2019 \text { [148]; } \\
\text { Cueva et al. } 2020 \text { [149] }\end{array}$ & Red wine Polyphenols & In vivo & Human & $\begin{array}{l}\text { Modulation of the gut microbiota composition } \\
\downarrow \text { Growth of pathogenic bacterial species } \\
\text { (F. nucleatum and P. Gingivalis) } \\
\downarrow \text { Adhesion to oral cells } \\
\downarrow \text { Risk of CRC }\end{array}$ \\
\hline \multicolumn{5}{|l|}{ Probiotics } \\
\hline Hatakka et al. 2008 [169] & $\begin{array}{l}\text { Lactobacillus rhamnosus } L C 705 \text { and } \\
\text { Propionibacterium freudenreichii ssp. }\end{array}$ & In vivo & Human & $\begin{array}{l}\text { Fecal counts of Lactobacilli and Propionibacteria } \\
\downarrow \beta \text {-glucosidase activity } \\
\uparrow C R C \text { prevention }\end{array}$ \\
\hline
\end{tabular}


Table 1. Cont.

\begin{tabular}{|c|c|c|c|c|}
\hline Study (Reference) & Dietary Mediator & Type of Study & Species & Most Relevant Results \\
\hline Vinderola et al. 2006 [171] & Lactobacillus kefiranofaciens & In vivo & Human & $\begin{array}{l}\text { Regulation of the immune system, } \\
\uparrow \text { Phagocytosis of tumor cells in early stages. }\end{array}$ \\
\hline $\begin{array}{l}\text { Galdeano et al. } 2007 \\
\text { [172] }\end{array}$ & Lactobacillus casei & In vivo & Mouse & $\begin{array}{l}\text { Induction of innate immunity influencing the } \\
\text { clonal expansion of IgA B-cell population, } \\
\downarrow \text { Risk of CRC. }\end{array}$ \\
\hline Bozkurt et al. 2019 [173] & Bifidobacterium animalis subsp. lactis & In vivo & $\begin{array}{l}\text { Human/ } \\
\text { Mouse }\end{array}$ & $\begin{array}{l}\uparrow \text { Production mycosporin-like amino acids } \\
\text { Modulation of the immune system to regulate the } \\
\text { proliferation and differentiation of intestinal } \\
\text { epithelial cells, macrophages, lymphocytes and } \\
\text { cytokine production }\end{array}$ \\
\hline Liu et al. 2011 [174] & $\begin{array}{l}\text { Lactobacillus plantarum, Lactobacillus } \\
\text { acidophilus \& Bifidobacterium Longum }\end{array}$ & In vivo & Human & $\begin{array}{l}\uparrow \text { Integrity of the intestinal barrier, } \\
\uparrow \text { Gut microbiota balance } \\
\downarrow \text { Post-operative infection rate }\end{array}$ \\
\hline Rafter et al. 2007 [175] & $\begin{array}{c}\text { Lactobacillus rhamnosus } \mathcal{E} \text { Bifidobacterium } \\
\text { lactis }\end{array}$ & In vivo & Human & $\begin{array}{l}\text { Modulation of the gut microbiota composition } \\
\downarrow \text { Intestinal permeability, } \\
\downarrow \text { Cancer biomarkers (cell proliferation). }\end{array}$ \\
\hline Hibberd et al. 2017 [176] & $\begin{array}{l}\text { Bifidobacterium animalis subsp. lactis } \\
\text { Bl-04 \& Lactobacillus acidophilus NCFM }\end{array}$ & In vivo & Human & $\begin{array}{l}\uparrow \text { Abundance of butyrate-producing bacteria in } \\
\text { tumor, mucosa and fecal samples }\end{array}$ \\
\hline Wan et al. 2014 [178] & Lactobacillus delbrueckii & In vitro & Cell line SW620 & $\begin{array}{l}\downarrow \text { Proliferation of colon cancer cells } \\
\uparrow \text { Apoptosis of colon cancer cells (via caspase } 3 \\
\text { pathway) }\end{array}$ \\
\hline Konishi et al. 2016 [179] & Lactobacillus casei strain ATCC 334 & In vivo & Human & $\begin{array}{l}\uparrow \text { Production of ferrichrome } \\
\uparrow \text { Apoptosis of colon cancer cells (via JNK } \\
\text { pathway) } \\
\downarrow \text { Progression of CRC }\end{array}$ \\
\hline $\begin{array}{l}\text { Chang et al. } \\
2018 \text { [182] }\end{array}$ & $\begin{array}{l}\text { Lactobacillus casei Variety rhamnosus } \mathcal{E} \\
\text { 5-FU/oxaliplatin }\end{array}$ & In vivo & Mouse & $\begin{array}{l}\downarrow \text { Intestinal mucositis derived from anticancer } \\
\text { treatment. }\end{array}$ \\
\hline $\begin{array}{l}\text { Ding et al. } 2018 \text { [183]; } \\
\text { Lee et al. } 2016 \text { [184]; } \\
\text { Routy et al. } 2018 \text { [185] }\end{array}$ & $\begin{array}{c}\text { Bifidobacterium } \mathcal{E} \\
\text { PD-1-based immunotherapy }\end{array}$ & In vivo & $\begin{array}{l}\text { Human/ } \\
\text { Mouse }\end{array}$ & $\begin{array}{l}\downarrow \text { Tumor growth } \\
\downarrow \text { Side effects induced by PD-1-based } \\
\text { immunotherapy }\end{array}$ \\
\hline Osterlund et al. 2007 [186] & Lactobacillus rhamnosus & In vivo & Human & $\begin{array}{l}\downarrow \text { Side effects (severe diarrhea, abdominal distress) } \\
\text { induced by chemotherapy. }\end{array}$ \\
\hline
\end{tabular}




\section{Conclusions}

Different animal and human studies have revealed that the microbial composition has been altered in precancerous colorectal lesions and in CRC. Moreover, a dysbiosis in gut microbiota has been found in CRC patients compared with healthy controls, with enrichment in pro-inflammatory opportunistic pathogens and a decrease in butyrate-producing bacteria. The proposed mechanisms by which the gut microbiota dysbiosis could participate in colorectal carcinogenesis are the impairment of the intestinal epithelial barrier function, the triggering of proinflammatory responses, the biosynthesis of genotoxins that can interfere with cell cycle regulation, and the production of toxic metabolites by pathogenic bacteria. Moreover, some lysogenic bacteriophages from gut virome could alter bacterial populations (by promoting bacterial lysis) in the colon, which could indirectly result in tumor progression. In addition, ecological analyses revealed synergistic intrafungal and antagonistic bacterial-fungal interactions in colorectal carcinogenesis, suggesting that gut mycobiota may also contribute to colorectal tumorigenesis.

In patients with CRC bacteria biofilm formation was associated with a host-enhanced polyamine metabolism, which may significantly contribute to the inflammation and cellular proliferation of colon cancer cells. Antibiotics were associated with CRC risk, but the effect depends on anatomical location and the type of antibiotics. On the other hand, previous epidemiological and clinical research studies have demonstrated that diet plays an important role in the promotion or inhibition of CRC, and gut microbiota is one of the most important links between them. High-fiber diets can significantly reduce the risk of CRC development. Soluble fiber is fermented into SCFAs by bacteria in the large intestine, and SCFAs (especially butyrate) has been shown to exhibit potential anti-carcinogenic effects in in vivo colon cancer models by modulating the local immune response and the protection of the intestinal barrier. Moreover, a high-fiber intake can increase the number of butyrate-producing bacteria in the gut. In addition, supplementation with PUFAs, polyphenols and probiotics could be used as therapeutical approaches for the reduction of CRC risk in a primary prevention setting, and it may also be used as adjuvants to conventional treatment for CRC, given the fact that the intestinal microbiota may modulate and enhance response to cancer therapy and reduce toxicity.

Thus, taking all this evidence together, gut microbiota should be considered as a key factor that can contribute to both the initiation and development of CRC. In addition, the dietary modulation of cancer-associated microbiome, through the intake of dietary components able to avoid dysbiosis and intestinal inflammation or to help modulate response to cancer therapy, could be an efficient strategy to prevent the development and progression of CRC and improve the efficacy of therapy.

Author Contributions: A Conceptualization, M.I.Q.-O. and J.G.-M.; methodology, L.S.-A., B.R.-M and A.L.-I.; validation, A.O., R.O. and J.A.M.; writing-original draft preparation, M.I.Q.-O., J.G.-M., L.S.-A. and B.R.-M.; writing-review and editing, all authors; funding acquisition, M.I.Q.-O.; supervision, M.I.Q.-O. and J.G.-M. All authors have read and agreed to the published version of the manuscript.

Funding: This work was supported by PI15/00256 from the Institute of Health "Carlos III" (ISCIII), co-funded by the Fondo Europeo de Desarrollo Regional-FEDER. Maria Isabel Queipo-Ortuño was supported by the "Miguel Servet Type II" program (CPI13/00003, ISCIII, Spain; co-funded by the Fondo Europeo de Desarrollo Regional-FEDER), and by the "Nicolas Monardes" research program of the Consejería de Salud (C-0030-2018, Junta de Andalucía, Spain. Bruno Ramos Molina was supported by a "Miguel Servet Type I" program (CP19/00098, ISCIII, Spain; co-funded by the Fondo Europeo de Desarrollo Regional-FEDER). Lidia Sanchez-Alcoholado was recipient of a predoctoral grant (PE-0106-2019) from the Consejería de Salud y Familia (co-funded by the Fondo Europeo de Desarrollo Regional-FEDER, Andalucia, Spain). Aurora Laborda-Illanes was recipient of a predoctoral grant PFIS-ISCIII (FI19-00112) co-funded by the Fondo Europeo de Desarrollo Regional-FEDER, Madrid, Spain.

Acknowledgments: We thank Richard Carlsson for help with the English language.

Conflicts of Interest: The authors declare no conflict of interest. 


\section{References}

1. Rubinstein, M.R.; Wang, X.; Liu, W.; Hao, Y.; Cai, G.; Han, Y.W. Fusobacterium nucleatum promotes colorectal carcinogenesis by modulating E-cadherin/ $\beta$-catenin signaling via its FadA adhesin. Cell Host Microbe 2013, 14, 195-206. [CrossRef] [PubMed]

2. Kostic, A.; Chun, E.; Robertson, L.; Glickman, J.N.; Gallini, C.A.; Michaud, M.; Clancy, T.E.; Chung, D.C.; Lochhead, P.; Hold, G.L.; et al. Fusobacterium nucleatum potentiates intestinal tumorigenesis and modulates the tumor-immune microenvironment. Cell Host Microbe 2013, 14, 207-215. [CrossRef] [PubMed]

3. Rooks, M.G.; Garrett, W.S. Gut microbiota, metabolites and host immunity. Nat. Rev. Immunol. 2016, 16, 341-352. [CrossRef] [PubMed]

4. $\quad$ Benson, A.K.; Kelly, S.A.; Legge, R.; Ma, F.; Low, S.J.; Kim, J.; Zhang, M.; Oh, P.L.; Nehrenberg, D.; Hua, K.; et al. Individuality in gut microbiota composition is a complex polygenic trait shaped by multiple environmental and host genetic factors. Proc. Natl. Acad. Sci. USA 2010, 107, 18933-18938. [CrossRef] [PubMed]

5. Costello, E.K.; Lauber, C.L.; Hamady, M.; Fierer, N.; Gordon, J.I.; Knight, R. Bacterial Community Variation in Human Body Habitats Across Space and Time. Science 2009, 326, 1694-1697. [CrossRef] [PubMed]

6. Wu, G.D.; Chen, J.; Hoffmann, C.; Bittinger, K.; Chen, Y.-Y.; Keilbaugh, S.A.; Bewtra, M.; Knights, D.; Walters, W.A.; Knight, R.; et al. Linking Long-Term Dietary Patterns with Gut Microbial Enterotypes. Science 2011, 334, 105-108. [CrossRef]

7. Gagnière, J.; Raisch, J.; Veziant, J.; Barnich, N.; Bonnet, R.; Buc, E.; Bringer, M.-A.; Pezet, D.; Bonnet, M. Gut microbiota imbalance and colorectal cancer. World J. Gastroenterol. 2016, 22, 501-518. [CrossRef]

8. Bhat, M.I.; Kapila, R. Dietary metabolites derived from gut microbiota: Critical modulators of epigenetic changes in mammals. Nutr. Rev. 2017, 75, 374-389. [CrossRef]

9. Jahani-Sherafat, S.; Alebouyeh, M.; Moghim, S.; Amoli, H.A.; Safaei, H.G. Role of gut microbiota in the pathogenesis of colorectal cancer; a review article. Gastroenterol. Hepatol. Bed Bench 2018, 11, 101-109.

10. Ferlay, J.; Soerjomataram, I.; Dikshit, R.; Eser, S.; Mathers, C.; Rebelo, M.; Parkin, N.M.; Forman, D.; Bray, F. Cancer incidence and mortality worldwide: Sources, methods and major patterns in Globocan 2012. Int. J. Cancer 2014, 136, 359-386. [CrossRef]

11. Feng, Q.; Liang, S.; Jia, H.; Stadlmayr, A.; Tang, L.; Lan, Z.; Zhang, D.; Xia, H.; Xu, X.; Jie, Z.; et al. Gut microbiome development along the colorectal adenoma-carcinoma sequence. Nat. Commun. 2015, 6, 6528. [CrossRef] [PubMed]

12. Nakatsu, G.; Li, X.; Zhou, H.; Sheng, J.; Wong, S.H.; Wu, W.K.; Ng, S.C.; Tsoi, H.; Dong, Y.; Zhang, N.; et al. Gut mucosal microbiome across stages of colorectal carcinogenesis. Nat. Commun. 2015, 6, 8727. [CrossRef]

13. Yu, J.; Feng, Q.; Wong, S.H.; Zhang, D.; Liang, J.Q.; Qin, Y.; Tang, L.; Zhao, H.; Stenvang, J.; Li, Y.; et al. Metagenomic analysis of faecal microbiome as a tool towards targeted non-invasive biomarkers for colorectal cancer. Gut 2015, 66, 70-78. [CrossRef] [PubMed]

14. Watson, A.J.M.; Collins, P.D. Colon Cancer: A Civilization Disorder. Dig. Dis. 2011, 29, 222-228. [CrossRef] [PubMed]

15. Cipe, G.; Idiz, U.O.; Firat, D.; Bektasoglu, H. Relationship between intestinal microbiota and colorectal cancer. World J. Gastrointest. Oncol. 2015, 7, 233-240. [CrossRef] [PubMed]

16. Zackular, J.P.; Baxter, N.; Iverson, K.D.; Sadler, W.D.; Petrosino, J.F.; Chen, G.Y.; Schloss, P.D. The Gut Microbiome Modulates Colon Tumorigenesis. mBio 2013, 4, 692-713. [CrossRef]

17. Chen, W.; Liu, F.; Ling, Z.; Tong, X.; Xiang, C. Human Intestinal Lumen and Mucosa-Associated Microbiota in Patients with Colorectal Cancer. PLoS ONE 2012, 7, e39743. [CrossRef]

18. Saffarian, A.; Mulet, C.; Regnault, B.; Amiot, A.; Tran-Van-Nhieu, J.; Ravel, J.; Sobhani, I.; Sansonetti, P.J.; Pédron, T.; Barnich, N.; et al. Crypt- and Mucosa-Associated Core Microbiotas in Humans and Their Alteration in Colon Cancer Patients. mBio 2019, 10, 1315-1319. [CrossRef]

19. Wang, T.; Cai, G.; Qiu, Y.; Fei, N.; Zhang, M.; Pang, X.; Jia, W.; Cai, S.; Zhao, L. Structural segregation of gut microbiota between colorectal cancer patients and healthy volunteers. ISME J. 2011, 6, 320-329. [CrossRef]

20. Shen, X.J.; Rawls, J.F.; Randall, T.A.; Burcal, L.; Mpande, C.N.; Jenkins, N.; Jovov, B.; Abdo, Z.; Sandler, R.S.; Keku, T.O. Molecular characterization of mucosal adherent bacteria and associations with colorectal adenomas. Gut Microbes 2010, 1, 138-147. [CrossRef]

21. Gao, Z.; Guo, B.; Gao, R.; Zhu, Q.; Wu, W.; Qin, H. Probiotics modify human intestinal mucosa-associated microbiota in patients with colorectal cancer. Mol. Med. Rep. 2015, 12, 6119-6127. [CrossRef] [PubMed] 
22. Ahn, J.; Sinha, R.; Pei, Z.; Dominianni, C.; Wu, J.; Shi, J.; Goedert, J.J.; Hayes, R.B.; Yang, L. Human gut microbiome and risk for colorectal cancer. J. Natl. Cancer Inst. 2013, 105, 1907-1911. [CrossRef] [PubMed]

23. Viljoen, K.S.; Dakshinamurthy, A.; Goldberg, P.; Blackburn, J.M. Quantitative Profiling of Colorectal Cancer-Associated Bacteria Reveals Associations between Fusobacterium spp., Enterotoxigenic Bacteroides fragilis (ETBF) and Clinicopathological Features of Colorectal Cancer. PLoS ONE 2015, 10, e0119462. [CrossRef] [PubMed]

24. Tjalsma, H.; Boleij, A.; Marchesi, J.R.; Dutilh, B.E. A bacterial controlador-passenger model for colorectal cancer: Beyond the usual suspects. Nat. Rev. Genet. 2012, 10, 575-582. [CrossRef] [PubMed]

25. McCoy, A.N.; Araujo-Perez, F.; Azcarate-Peril, M.A.; Yeh, J.J.; Sandler, R.S.; Keku, T.O. Fusobacterium Is Associated with Colorectal Adenomas. PLoS ONE 2013, 8, e53653. [CrossRef] [PubMed]

26. Peters, B.A.; Dominianni, C.; Shapiro, J.A.; Church, T.R.; Wu, J.; Miller, G.; Yuen, E.; Freiman, H.; Lustbader, I.; Salik, J.; et al. The gut microbiota in conventional and serrated precursors of colorectal cancer. Microbiome 2016, 4, 69. [CrossRef]

27. Yu, T.; Guo, F.; Yu, Y.; Sun, T.; Ma, D.; Han, J.; Qian, Y.; Kryczek, I.; Sun, D.; Nagarsheth, N.; et al. Fusobacterium nucleatum Promotes Chemoresistance to Colorectal Cancer by Modulating Autophagy. Cell 2017, 170, 548-563.e16. [CrossRef]

28. Li, Y.; Kundu, P.; Seow, S.W.; de Matos, C.T.; Aronsson, L.; Chin, K.C.; Kärre, K.; Pettersson, S.; Greicius, G. Gut microbiota accelerate tumor growth via c-jun and STAT3 phosphorylation in APC Min/+ mice. Carcinogenesis 2012, 33, 1231-1238. [CrossRef]

29. Takeda, K.; Clausen, B.E.; Kaisho, T.; Tsujimura, T.; Terada, N.; Förster, I.; Akira, S. Enhanced Th1 activity and development of chronic enterocolitis in mice devoid of Stat3 in macrophages and neutrophils. Immunity 1999, 10, 39-49. [CrossRef]

30. Uronis, J.M.; Mühlbauer, M.; Herfarth, H.H.; Rubinas, T.C.; Jones, G.; Jobin, C. Modulation of the Intestinal Microbiota Alters Colitis-Associated Colorectal Cancer Susceptibility. PLoS ONE 2009, 4, e6026. [CrossRef]

31. Grivennikov, S.I.; Wang, K.; Mucida, D.; Stewart, C.A.; Schnabl, B.; Jauch, D.; Taniguchi, K.; Yu, G.-Y.; Österreicher, C.H.; Hung, K.E.; et al. Adenoma-linked barrier defects and microbial products drive IL-23/IL-17-mediated tumour growth. Nature 2012, 491, 254-258. [CrossRef] [PubMed]

32. Kostovcikova, K.; Kverka, M.; Zakostelska, Z.; Hudcovic, T.; Hrncir, T.; Stepankova, R.; Rossmann, P.; Ridl, J.; Kostovcikova, K.; Mrázek, J.; et al. Altered gut microbiota promotes colitis-associated cancer in IL-1 receptor-associated kinase M-deficient mice. Inflamm. Bowel Dis. 2013, 19, 1266-1277. [CrossRef]

33. Coelho, T.R.; Almeida, L.; Lazo, P.A. JC virus in the pathogenesis of colorectal cancer, an etiological agent or another component in a multistep process? Virol. J. 2010, 7, 42. [CrossRef] [PubMed]

34. Damin, D.C.; Ziegelmann, P.K.; Damin, A.P. Human papillomavirus infection and colorectal cancer risk: A meta-analysis. Color. Dis. 2013, 15, 420. [CrossRef] [PubMed]

35. Nakatsu, G.; Zhou, H.; Wu, W.K.K.; Wong, S.H.; Coker, O.O.; Dai, Z.; Li, X.; Szeto, C.H.; Sugimura, N.; Lam, T.Y.-T.; et al. Alterations in Enteric Virome Are Associated With Colorectal Cancer and Survival Outcomes. Gastroenterology 2018, 155, 529-541. [CrossRef] [PubMed]

36. Hannigan, G.; Duhaime, M.B.; Ruffin, M.; Koumpouras, C.C.; Schloss, P.D. Diagnostic Potential and Interactive Dynamics of the Colorectal Cancer Virome. mBio 2018, 9, 2248-2318. [CrossRef]

37. Zheng, D.-W.; Dong, X.; Pan, P.; Chen, K.-W.; Fan, J.-X.; Cheng, S.-X.; Zhang, X.-Z. Phage-guided modulation of the gut microbiota of mouse models of colorectal cancer augments their responses to chemotherapy. Nat. Biomed. Eng. 2019, 3, 717-728. [CrossRef]

38. Luan, C.; Xie, L.; Yang, X.; Miao, H.; Lv, N.; Zhang, R.; Xiao, X.; Hu, Y.; Liu, Y.; Wu, N.; et al. Dysbiosis of Fungal Microbiota in the Intestinal Mucosa of Patients with Colorectal Adenomas. Sci. Rep. 2015, 5, 7980. [CrossRef]

39. Coker, O.O.; Nakatsu, G.; Dai, R.Z.; Wu, W.K.K.; Wong, S.H.; Ng, S.C.; Chan, F.K.L.; Sung, J.J.; Yu, J. Enteric fungal microbiota dysbiosis and ecological alterations in colorectal cancer. Gut 2018, 68, 654-662. [CrossRef]

40. Gao, R.; Kong, C.; Li, H.; Huang, L.; Qu, X.; Qin, N.; Qin, H. Dysbiosis signature of mycobiota in colon polyp and colorectal cancer. Eur. J. Clin. Microbiol. Infect. Dis. 2017, 36, 2457-2468. [CrossRef]

41. Grivennikov, S. Inflammation and colorectal cancer: Colitis-associated neoplasia. Semin. Immunopathol. 2012, 35, 229-244. [CrossRef] [PubMed]

42. Francescone, R.; Hou, V.; Grivennikov, S. Microbiome, inflammation, and cancer. Cancer J. 2014, 20, 181-189. [CrossRef] [PubMed] 
43. Dzutsev, A.; Goldszmid, R.S.; Viaud, S.; Zitvogel, L.; Trinchieri, G. The role of the microbiota in inflammation, carcinogenesis, and cancer therapy. Eur. J. Immunol. 2014, 45, 17-31. [CrossRef] [PubMed]

44. Bongers, G.; Pacer, M.E.; Geraldino, T.H.; Chen, L.; He, Z.; Hashimoto, D.; Furtado, G.C.; Ochando, J.; Kelley, K.A.; Clemente, J.C.; et al. Interplay of host microbiota, genetic perturbations, and inflammation promotes local development of intestinal neoplasms in mice. J. Exp. Med. 2014, 211, 457-472. [CrossRef] [PubMed]

45. Hu, B.; Elinav, E.; Huber, S.; Strowig, T.; Hao, L.; Hafemann, A.; Jin, C.; Wunderlich, C.; Wunderlich, T.; Eisenbarth, S.C.; et al. Microbiota-induced activation of epithelial IL-6 signaling links inflammasome-driven inflammation with transmissible cancer. Proc. Natl. Acad. Sci. USA 2013, 110, 9862-9867. [CrossRef] [PubMed]

46. Moore, W.E.; Moore, L.H. Intestinal floras of populations that have a high risk of CRC cancer. Appl. Environ. Microbiol. 1995, 61, 3202-3207. [CrossRef]

47. Goodwin, A.C.; Shields, C.E.D.; Wu, S.; Huso, D.L.; Wu, X.; Stewart, T.M.; Hacker-Prietz, A.; Rabizadeh, S.; Woster, P.M.; Sears, C.L.; et al. Polyamine catabolism contributes to enterotoxigenic Bacteroides fragilis-induced colon tumorigenesis. Proc. Natl. Acad. Sci. USA 2011, 108, 15354-15359. [CrossRef]

48. Wu, S.; Shin, J.; Zhang, G.; Cohen, M.B.; Franco, A.; Sears, C. The Bacteroides fragilis Toxin Binds to a Specific Intestinal Epithelial Cell Receptor. Infect. Immun. 2006, 74, 5382-5390. [CrossRef]

49. Vizcaino, M.I.; Crawford, J. The colibactin warhead crosslinks DNA. Nat. Chem. 2015, 7, 411-417. [CrossRef]

50. Rubinstein, M.R.; Baik, J.E.; Lagana, S.M.; Han, R.P.; Raab, W.J.; Sahoo, D.; Dalerba, P.; Wang, T.C.; Han, Y.W. Fusobacterium nucleatum promotes colorectal cancer by inducing Wnt/ $\beta$-catenin modulator Annexin A1. EMBO Rep. 2019, 20, e47638. [CrossRef]

51. Brennan, C.A.; Garrett, W.S. Fusobacterium nucleatum-symbiont, opportunist and oncobacterium. Nat. Rev. Genet. 2018, 17, 156-166. [CrossRef]

52. Louis, P.; Hold, G.L.; Flint, H.J. The gut microbiota, bacterial metabolites and colorectal cancer. Nat. Rev. Genet. 2014, 12, 661-672. [CrossRef] [PubMed]

53. Thomas, A.M.; Manghi, P.; Asnicar, F.; Pasolli, E.; Armanini, F.; Zolfo, M.; Beghini, F.; Manara, S.; Karcher, N.; Pozzi, C.; et al. Metagenomic analysis of colorectal cancer datasets identifies cross-cohort microbial diagnostic signatures and a enlace with choline degradation. Nat. Med. 2019, 25, 667-678. [CrossRef] [PubMed]

54. Soda, K. The mechanisms by which polyamines accelerate tumor spread. J. Exp. Clin. Cancer Res. 2011, 30, 95. [CrossRef] [PubMed]

55. Casero, R.A.; Stewart, T.M.; Pegg, A.E. Polyamine metabolism and cancer: Treatments, challenges and opportunities. Nat. Rev. Cancer 2018, 18, 681-695. [CrossRef] [PubMed]

56. Love, R.R.; Surawicz, T.S.; Morrissey, J.F.; Verma, A.K. Levels of colorectal ornithine decarboxylase activity in patients with colon cancer, a family history of nonpolyposis hereditary colorectal cancer, and adenomas. Cancer Epidemiol. Biomark. Prev. 1992, 1, 195-198.

57. Linsalata, M.; Russo, F.; Cavallini, A.; Berloco, P.; di Leo, A. Polyamines, diamine oxidase, and ornithine decarboxylase activity in colorectal cancer and in normal surrounding mucosa. Dis. Colon Rectum 1993, 36, 662-667. [CrossRef]

58. Meyskens, F.L.; McLaren, C.E.; Pelot, D.; Fujikawa-Brooks, S.; Carpenter, P.M.; Hawk, E.; Kelloff, G.; Lawson, M.J.; Kidao, J.; McCracken, J.; et al. Difluoromethylornithine Plus Sulindac for the Prevention of Sporadic Colorectal Adenomas: A Randomized Placebo-Controlled, Double-Blind Trial. Cancer Prev. Res. 2008, 1, 32-38. [CrossRef]

59. Raj, K.P.; Zell, J.A.; Rock, C.L.; McLaren, C.; Zoumas-Morse, C.; Gerner, E.W.; Meyskens, F.L. Role of dietary polyamines in a phase III clinical trial of difluoromethylornithine (DFMO) and sulindac for prevention of sporadic colorectal adenomas. Br. J. Cancer 2013, 108, 512-518. [CrossRef]

60. Ramos-Molina, B.; Queipo-Ortuño, M.I.; Lambertos, A.; Tinahones, F.J.; Peñafiel, R. Dietary and Gut Microbiota Polyamines in Obesity- and Age-Related Diseases. Front. Nutr. 2019, 6, 24. [CrossRef]

61. Tofalo, R.; Cocchi, S.; Suzzi, G. Polyamines and Gut Microbiota. Front. Nutr. 2019, 6, 16. [CrossRef] [PubMed]

62. Hessels, J.; Kingma, A.W.; Ferwerda, H.; Keu, J.; Berg, G.A.V.D.; Muskiet, F.A.J. Microbial flora in the gastrointestinal tract abolishes cytostatic effects of $\alpha$-difluoromethylornithinein vivo. Int. J. Cancer 1989, 43, 1155-1164. [CrossRef] [PubMed]

63. Quemener, V.; Blanchard, Y.; Chamaillard, L.; Havouis, R.; Cipolla, B.; Moulinoux, J.P. Polyamine deprivation: A new tool in cancer treatment. Anticancer Res. 1994, 14, 443-448. [PubMed] 
64. Gamble, L.D.; Purgato, S.; Murray, J.; Xiao, L.; Yu, D.M.T.; Hanssen, K.M.; Giorgi, F.M.; Carter, D.R.; Gifford, A.J.; Valli, E.; et al. Inhibition of polyamine synthesis and uptake reduces tumor progression and prolongs survival in mouse models of neuroblastoma. Sci. Transl. Med. 2019, 11, e1099. [CrossRef] [PubMed]

65. Dejea, C.M.; Wick, E.C.; Hechenbleikner, E.M.; White, J.R.; Welch, J.L.M.; Rossetti, B.J.; Peterson, S.N.; Snesrud, E.C.; Borisy, G.G.; Lazarev, M.; et al. Microbiota organization is a distinct feature of proximal colorectal cancers. Proc. Natl. Acad. Sci. USA 2014, 111, 18321-18326. [CrossRef]

66. Johnson, C.H.; Dejea, C.M.; Edler, D.; Hoang, L.T.; Santidrian, A.F.; Felding, B.H.; Ivanisevic, J.; Cho, K.; Wick, E.C.; Hechenbleikner, E.M.; et al. Metabolism links bacterial biofilms and colon carcinogenesis. Cell Metab. 2015, 21, 891-897. [CrossRef]

67. Wu, N.; Yang, X.; Zhang, R.; Li, J.; Xiao, X.; Hu, Y.; Chen, Y.; Yang, F.; Lu, N.; Wang, Z.; et al. Dysbiosis Signature of Fecal Microbiota in Colorectal Cancer Patients. Microb. Ecol. 2013, 66, 462-470. [CrossRef]

68. Brown, D.; Rao, S.; Weir, T.L.; O’Malia, J.; Bazan, M.; Brown, R.J.; Ryan, E.P. Metabolomics and metabolic pathway networks from human colorectal cancers, adjacent mucosa, and stool. Cancer Metab. 2016, 4, 11. [CrossRef]

69. Salcedo, R.; Worschech, A.; Cardone, M.; Jones, Y.; Gyulai, Z.; Dai, R.-M.; Wang, E.; Ma, W.; Haines, D.; O'Huigin, C.; et al. MyD88-mediated signaling prevents development of adenocarcinomas of the colon: Role of interleukin 18. J. Exp. Med. 2010, 207, 1625-1636. [CrossRef]

70. Vaishnava, S.; Behrendt, C.L.; Ismail, A.S.; Eckmann, L.; Hooper, L.V. Paneth cells directly sense gut commensals and maintain homeostasis at the intestinal host-microbial interfaz. Proc. Natl. Acad. Sci. USA 2008, 105, 20858-20863. [CrossRef]

71. Dupaul-Chicoine, J.; Yeretssian, G.; Doiron, K.; Bergstrom, K.S.; McIntire, C.R.; Leblanc, P.M.; Meunier, C.; Turbide, C.; Gros, P.; Beauchemin, N.; et al. Control of Intestinal Homeostasis, Colitis, and Colitis-Associated Colorectal Cancer by the Inflammatory Caspases. Immunity 2010, 32, 367-378. [CrossRef] [PubMed]

72. Allen, I.C.; TeKippe, E.M.; Woodford, R.-M.T.; Uronis, J.M.; Holl, E.K.; Rogers, A.B.; Herfarth, H.H.; Jobin, C.; Ting, J.P.-Y. The NLRP3 inflammasome functions as a negative regulator of tumorigenesis during colitis-associated cancer. J. Exp. Med. 2010, 207, 1045-1056. [CrossRef] [PubMed]

73. Elinav, E.; Strowig, T.; Kau, A.; Henao-Mejia, J.; Thaiss, C.A.; Booth, C.J.; Peaper, D.R.; Bertin, J.; Eisenbarth, S.; Gordon, J.I.; et al. NLRP6 Inflammasome Regulates Colonic Microbial Ecology and Risk for Colitis. Cell 2011, 145, 745-757. [CrossRef] [PubMed]

74. Singh, N.; Gurav, A.; Sivaprakasam, S.; Brady, E.; Padia, R.; Shi, H.; Thangaraju, M.; Prasad, P.D.; Manicassamy, S.; Munn, D.H.; et al. Activation of Gpr109a, receptor for niacin and the commensal metabolite butyrate, suppresses colonic inflammation and carcinogenesis. Immunity 2014, 40, 128-139. [CrossRef]

75. Martin, O.C.B.; Lin, C.; Naud, N.; Tache, S.; Raymond-Letron, I.; Corpet, D.E.; Pierre, F.H. Antibiotic Suppression of Intestinal Microbiota Reduces Heme-Induced Lipoperoxidation Associated with Colon Carcinogenesis in Rats. Nutr. Cancer 2014, 67, 119-125. [CrossRef]

76. Dik, V.K.; van Oijen, M.G.H.; Smeets, H.M.; Siersema, P.D. Frequent Use of Antibiotics Is Associated with Colorectal Cancer Risk: Results of a Nested Case-Control Study. Dig. Dis. Sci. 2015, 61, 255-264. [CrossRef]

77. Boursi, B.; Haynes, K.; Mamtani, R.; Yang, Y.-X. Impact of antibiotic exposure on the risk of colorectal cancer. Pharmacoepidemiol. Drug Saf. 2015, 24, 534-542. [CrossRef]

78. Zackular, J.P.; Baxter, N.T.; Chen, G.Y.; Schloss, P.D. Manipulation of the Gut Microbiota Reveals Role in Colon Tumorigenesis. mSphere 2015, 1, e00001-15. [CrossRef]

79. Bullman, S.; Pedamallu, C.S.; Sicinska, E.; Clancy, T.E.; Zhang, X.; Cai, D.; Neuberg, D.S.; Huang, K.; Guevara, F.; Nelson, T.; et al. Analysis of Fusobacterium persistence and antibiotic response in colorectal cancer. Science 2017, 358, 1443-1448. [CrossRef]

80. Lee, J.G.; Eun, C.S.; Jo, S.V.; Lee, A.-R.; Park, C.H.; Han, D.S. The impact of gut microbiota manipulation with antibiotics on colon tumorigenesis in a murine model. PLoS ONE 2019, 14, e226907. [CrossRef]

81. Ma, W.; Chan, A.T. Antibiotic use and colorectal cancer: A causal association? Gut 2019. [CrossRef] [PubMed]

82. Wang, J.-L.; Chang, C.-H.; Lin, J.-W.; Wu, L.-C.; Chuang, L.-M.; Lai, M.-S. Infection, antibiotic therapy and risk of colorectal cancer: A nationwide nested case-control study in patients with Type 2 diabetes mellitus. Int. J. Cancer 2014, 135, 956-967. [CrossRef] [PubMed]

83. Gensollen, T.; Iyer, S.S.; Kasper, D.L.; Blumberg, R.S. How colonization by microbiota in early life shapes the immune system. Science 2016, 352, 539-544. [CrossRef] [PubMed] 
84. Cao, Y.; Wu, K.; Mehta, R.; Drew, D.; Song, M.; Lochhead, P.; Nguyen, L.H.; Izard, J.; Fuchs, C.S.; Garrett, W.S.; et al. Long-term use of antibiotics and risk of colorectal adenoma. Gut 2017, 67, 672-678. [CrossRef] [PubMed]

85. Montalban-Arques, A.; Scharl, M. Intestinal microbiota and colorectal carcinoma: Implications for pathogenesis, diagnosis, and therapy. eBioMedicine 2019, 48, 648-655. [CrossRef]

86. Zhang, J.; Haines, C.; Watson, A.J.M.; Hart, A.R.; Platt, M.J.; Pardoll, D.M.; E Cosgrove, S.; A Gebo, K.; Sears, C.L. Oral antibiotic use and risk of colorectal cancer in the United Kingdom, 1989-2012: A matched case-control study. Gut 2019, 68, 1971-1978. [CrossRef]

87. Sanyaolu, L.N.; Oakley, N.J.; Nurmatov, U.; Dolwani, S.; Ahmed, H. Antibiotic exposure and the risk of colorectal adenoma and carcinoma: A systematic review and meta-analysis of observational studies. Color. Dis. 2019. [CrossRef]

88. Armstrong, D.; Dregan, A.; Ashworth, M.; White, P.; McGee, C.; de Lusignan, S. The association between colorectal cancer and prior antibiotic prescriptions: Case control study. Br. J. Cancer 2020, 122, 912-917. [CrossRef]

89. Yuan, L.; Zhang, S.; Li, H.; Yang, F.; Mushtaq, N.; Ullah, S.; Shi, Y.; An, C.; Xu, J. The influence of gut microbiota dysbiosis to the efficacy of 5-Fluorouracil treatment on colorectal cancer. Biomed. Pharmacother. 2018, 108, 184-193. [CrossRef]

90. Abdel-Rahman, O.; Ghosh, S.; Walker, J. Outcomes of metastatic colorectal cancer patients in relationship to prior and concurrent antibiotics use; individual patient data analysis of three clinical trials. Clin. Transl. Oncol. 2020, 1-6. [CrossRef]

91. Vétizou, M.; Pitt, J.M.; Daillère, R.; Lepage, P.; Waldschmitt, N.; Flament, C.; Rusakiewicz, S.; Routy, B.; Roberti, M.P.; Duong, C.P.; et al. Anticancer immunotherapy by CTLA-4 blockade relies on the gut microbiota. Science 2015, 350, 1079-1084. [CrossRef] [PubMed]

92. Leystra, A.; Clapper, M.L. Gut Microbiota Influences Experimental Outcomes in Mouse Models of Colorectal Cancer. Genes 2019, 10, 900. [CrossRef] [PubMed]

93. Lattimer, J.M.; Haub, M. Effects of Dietary Fiber and Its Components on Metabolic Health. Nutrients 2010, 2, 1266-1289. [CrossRef] [PubMed]

94. Zeng, H.; Lazarova, D.L.; Bordonaro, M. Mechanisms linking dietary fiber, gut microbiota and colon cancer prevention. World J. Gastrointest. Oncol. 2014, 6, 41-51. [CrossRef] [PubMed]

95. Bingham, S.; Day, N.; Luben, R.N.; Ferrari, P.; Slimani, N.; Norat, T.; Clavel-Chapelon, F.; Kesse, E.; Nieters, A.; Boeing, H.; et al. Dietary fibre in food and protection against colorectal cancer in the European Prospective Investigation into Cancer and Nutrition (EPIC): An observational study. Lancet 2003, 361, 1496-1501. [CrossRef]

96. Schatzkin, A.; Mouw, T.; Park, Y.; Subar, A.F.; Kipnis, V.; Hollenbeck, A.; Leitzmann, M.F.; E Thompson, F. Dietary fiber and whole-grain consumption in relation to colorectal cancer in the NIH-AARP Diet and Health Study. Am. J. Clin. Nutr. 2007, 85, 1353-1360. [CrossRef]

97. Dahm, C.C.; Keogh, R.H.; A Spencer, E.; Greenwood, D.; Key, T.J.; Fentiman, I.S.; Shipley, M.J.; Brunner, E.J.; Cade, J.E.; Burley, V.; et al. Dietary Fiber and Colorectal Cancer Risk: A Nested Case-Control Study Using Food Diaries. J. Natl. Cancer Inst. 2010, 102, 614-626. [CrossRef]

98. Dahm, C.C. Dietary fiber and colorectal cancer risk: A nested case-control study using food diaries. J. Natl. Cancer Inst. 2011, 103, 1484. [CrossRef]

99. Hansen, L.; Skeie, G.; Landberg, R.; Lund, E.; Palmqvist, R.; Johansson, I.; Dragsted, L.O.; Egeberg, R.; Johnsen, N.F.; Christensen, J.; et al. Intake of dietary fiber, especially from cereal foods, is associated with lower incidence of colon cancer in the HELGA cohort. Int. J. Cancer 2011, 131, 469-478. [CrossRef]

100. Song, M.; Wu, K.; Meyerhardt, J.A.; Ogino, S.; Wang, M.; Fuchs, C.S.; Giovannucci, E.L.; Chan, A.T. Fiber Intake and Survival After Colorectal Cancer Diagnosis. JAMA Oncol. 2018, 4, 71-79. [CrossRef]

101. Moen, B.; Henjum, K.; Mage, I.; Knutsen, S.H.; Rud, I.; Hetland, R.B.; Paulsen, J.E. Effect of Dietary Fibers on Cecal Microbiota and Intestinal Tumorigenesis in Azoxymethane Treated A/J Min/+ Mice. PLoS ONE 2016, 11, e0155402. [CrossRef] [PubMed]

102. Mehta, R.S.; Nishihara, R.; Cao, Y.; Song, M.; Mima, K.; Qian, Z.R.; Nowak, J.A.; Kosumi, K.; Hamada, T.; Masugi, Y.; et al. Association of Dietary Patterns With Risk of Colorectal Cancer Subtypes Classified by Fusobacterium nucleatum in Tumor Tissue. JAMA Oncol. 2017, 3, 921-927. [CrossRef] [PubMed] 
103. Deehan, E.C.; Yang, C.; Perez-Muñoz, M.E.; Nguyen, N.K.; Cheng, C.C.; Triador, L.; Zhang, Z.; Bakal, J.A.; Walter, J. Precision Microbiome Modulation with Discrete Dietary Fiber Structures Directs Short-Chain Fatty Acid Production. Cell Host Microbe 2020, 27, 389-404. [CrossRef] [PubMed]

104. Chen, H.-M.; Yu, Y.-N.; Wang, J.-L.; Lin, Y.-W.; Kong, X.; Yang, C.-Q.; Yang, L.; Liu, Z.; Yuan, Y.-Z.; Liu, F.; et al. Decreased dietary fiber intake and structural alteration of gut microbiota in patients with advanced colorectal adenoma. Am. J. Clin. Nutr. 2013, 97, 1044-1052. [CrossRef] [PubMed]

105. O'Keefe, S.J.D.; Li, J.V.; Lahti, L.; Ou, J.; Carbonero, F.; Mohammed, K.; Posma, J.M.; Kinross, J.M.; Wahl, E.; Ruder, E.; et al. Fat, fibre and cancer risk in African Americans and rural Africans. Nat. Commun. 2015, 6, 6342. [CrossRef] [PubMed]

106. Donohoe, D.R.; Holley, D.; Collins, L.B.; Montgomery, S.A.; Whitmore, A.C.; Hillhouse, A.; Curry, K.P.; Renner, S.W.; Greenwalt, A.; Ryan, E.P.; et al. A gnotobiotic mouse model demonstrates that dietary fiber protects against colorectal tumorigenesis in a microbiota- and butyrate-dependent manner. Cancer Discov. 2014, 4, 1387-1397. [CrossRef]

107. Bishehsari, F.; Engen, P.; Preite, N.Z.; Tuncil, Y.E.; Naqib, A.; Shaikh, M.; Rossi, M.; Wilber, S.; Green, S.J.; Hamaker, B.R.; et al. Dietary Fiber Treatment Corrects the Composition of Gut Microbiota, Promotes SCFA Production, and Suppresses Colon Carcinogenesis. Genes 2018, 9, 102. [CrossRef]

108. Burkitt, D.P. Epidemiology of cancer of the colon and rectum. Cancer 1971, 28, 3-13. [CrossRef]

109. Bergman, E.N. Energy contributions of volatile fatty acids from the gastrointestinal tract in various species. Physiol. Rev. 1990, 70, 567-590. [CrossRef]

110. Hamer, H.M.; Jonkers, D.; Venema, K.; Vanhoutvin, S.; Troost, F.J.; Brummer, R.J. Review article: The role of butyrate on colonic function. Aliment. Pharmacol. Ther. 2007, 27, 104-119. [CrossRef]

111. Fung, T.T.; Hu, F.B.; Schulze, M.B.; Pollak, M.; Wu, T.; Fuchs, C.S.; Giovannucci, E. A dietary pattern that is associated with C-peptide and risk of colorectal cancer in women. Cancer Causes Control. 2012, 23, 959-965. [CrossRef] [PubMed]

112. Neish, A.S. Microbes in gastrointestinal health and disease. Gastroenterology 2008, 136, 65-80. [CrossRef] [PubMed]

113. Volpato, M.; A Hull, M. Omega-3 polyunsaturated fatty acids as adjuvant therapy of colorectal cancer. Cancer Metastasis Rev. 2018, 37, 545-555. [CrossRef]

114. Costantini, L.; Molinari, R.; Farinon, B.; Merendino, N. Impact of Omega-3 Fatty Acids on the Gut Microbiota. Int. J. Mol. Sci. 2017, 18, 2645. [CrossRef]

115. Watson, H.; Mitra, S.; Croden, F.C.; Taylor, M.; Wood, H.M.; Perry, S.L.; A Spencer, J.; Quirke, P.; Toogood, G.J.; Lawton, C.L.; et al. A randomised trial of the effect of omega-3 polyunsaturated fatty acid supplements on the human intestinal microbiota. Gut 2017, 67, 1974-1983. [CrossRef]

116. Cho, Y.; Turner, N.D.; A Davidson, L.; Chapkin, R.S.; Carroll, R.J.; Lupton, J.R. Colon cancer cell apoptosis is induced by combined exposure to the $\mathrm{n}-3$ fatty acid docosahexaenoic acid and butyrate through promoter methylation. Exp. Boil. Med. 2014, 239, 302-310. [CrossRef]

117. Chapkin, R.S.; Declercq, V.; Kim, E.; Fuentes, N.; Fan, Y.-Y. Mechanisms by Which Pleiotropic Amphiphilic n-3 PUFA Reduce Colon Cancer Risk. Curr. Color. Cancer Rep. 2014, 10, 442-452. [CrossRef] [PubMed]

118. Triff, K.; Kim, E.; Chapkin, R.S. Chemoprotective Epigenetic Mechanisms in a Colorectal Cancer Model: Modulation by n-3 PUFA in Combination With Fermentable Fiber. Curr. Pharmacol. Rep. 2015, 1, 11-20. [CrossRef] [PubMed]

119. Hong, M.Y.; Turner, N.D.; Murphy, M.E.; Carroll, R.J.; Chapkin, R.S.; Lupton, J.R. In vivo regulation of colonic cell proliferation, differentiation, apoptosis, and P27Kip1 by dietary fish oil and butyrate in rats. Cancer Prev. Res. 2015, 8, 1076-1083. [CrossRef]

120. Piazzi, G.; D’Argenio, G.; Prossomariti, A.; Lembo, V.; Mazzone, G.; Candela, M.; Biagi, E.; Brigidi, P.; Vitaglione, P.; Fogliano, V.; et al. Eicosapentaenoic acid free fatty acid prevents and suppresses colonic neoplasia in colitis-associated colorectal cancer acting on Notch signaling and gut microbiota. Int. J. Cancer 2014, 135, 2004-2013. [CrossRef]

121. Lee, J.Y.; Sim, T.-B.; Lee, J.-E.; Na, H.-K. Chemopreventive and Chemotherapeutic Effects of Fish Oil derived Omega-3 Polyunsaturated Fatty Acids on Colon Carcinogenesis. Clin. Nutr. Res. 2017, 6, 147-160. [CrossRef] [PubMed] 
122. Song, M.; Nishihara, R.; Wu, K.; Qian, Z.R.; Kim, S.A.; Sukawa, Y.; Mima, K.; Inamura, K.; Masuda, A.; Yang, J.; et al. Marine $\omega-3$ Polyunsaturated Fatty Acids and Risk for Colorectal Cancer According to Microsatellite Instability. J. Natl. Cancer Inst. 2015, 107, e007. [CrossRef]

123. Lamprecht, S.A.; Lipkin, M. Chemoprevention of colon cancer by calcium, vitamin D and folate: Molecular mechanisms. Nat. Rev. Cancer 2003, 3, 601-614. [CrossRef] [PubMed]

124. Yang, K.; Li, H.; Dong, J.; Dong, Y.; Wang, C.-Z. Expression profile of polyunsaturated fatty acids in colorectal cancer. World J. Gastroenterol. 2015, 21, 2405-2412. [CrossRef] [PubMed]

125. Chang, W.-C.L.; Chapkin, R.S.; Lupton, J.R. Fish Oil Blocks Azoxymethane-Induced Rat Colon Tumorigenesis by Increasing Cell Differentiation and Apoptosis Rather Than Decreasing Cell Proliferation. J. Nutr. 1998, 128, 491-497. [CrossRef]

126. Song, M.; Zhang, X.; Meyerhardt, J.A.; Giovannucci, E.L.; Ogino, S.; Fuchs, C.S.; Chan, A.T. Marine $\omega-3$ polyunsaturated fatty acid intake and survival after colorectal cancer diagnosis. Gut 2016, 66, 1790-1796. [CrossRef]

127. Cho, Y.; Turner, N.D.; Davidson, L.; Chapkin, R.S.; Carroll, R.J.; Lupton, J.R. A chemoprotective fish oil/pectin diet enhances apoptosis via Bcl-2 promoter methylation in rat azoxymethane-induced carcinomas. Exp. Boil. Med. 2012, 237, 1387-1393. [CrossRef]

128. Ng, Y.; Barhoumi, R.; Tjalkens, R.B.; Fan, Y.-Y.; Kolar, S.; Wang, N.; Lupton, J.R.; Chapkin, R.S. The role of docosahexaenoic acid in mediating mitochondrial membrane lipid oxidation and apoptosis in colonocytes. Carcinogenesis 2005, 26, 1914-1921. [CrossRef]

129. Sofi, F.; Dinu, M.; Pagliai, G.; Pierre, F.; Gueraud, F.; Bowman, J.; Gerard, P.; Longo, V.; Giovannelli, L.; Caderni, G.; et al. Fecal microbiome as determinant of the effect of diet on colorectal cancer risk: Comparison of meat-based versus pesco-vegetarian diets (the MeaTIc study). Trials 2019, 20, 688-689. [CrossRef]

130. Aglago, E.K.; Huybrechts, I.; Murphy, N.; Casagrande, C.; Nicolas, G.; Pischon, T.; Fedirko, V.; Severi, G.; Boutron-Ruault, M.-C.; Fournier, A.; et al. Consumption of Fish and Long-chain n-3 Polyunsaturated Fatty Acids Is Associated With Reduced Risk of Colorectal Cancer in a Large European Cohort. Clin. Gastroenterol. Hepatol. 2020, 18, 654-666. [CrossRef]

131. Rani, I.; Sharma, B.; Kumar, S.; Kaur, S.; Agnihotri, N. Apoptosis mediated chemosensitization of tumor cells to 5-fluorouracil on supplementation of fish oil in experimental colon carcinoma. Tumor Boil. 2017, 39. [CrossRef] [PubMed]

132. Rani, I.; Vaiphei, K.; Agnihotri, N. Supplementation of fish oil augments efficacy and attenuates toxicity of 5-fluorouracil in 1,2-dimethylhydrazine dihydrochloride/dextran sulfate sodium-induced colon carcinogenesis. Cancer Chemother. Pharmacol. 2014, 74, 309-322. [CrossRef] [PubMed]

133. Sebe, M.; Tsutsumi, R.; Yamaguchi, S.; Horikawa, Y.T.; Harada, N.; Oyama, T.; Kakuta, N.; Tanaka, K.; Tsutsumi, Y.M.; Nakaya, Y.; et al. The synergystic effects of omega-3 fatty acids against 5-fluorouracil-induced mucosal impairment in mice. BMC Nutr. 2016, 2, 17. [CrossRef]

134. Ebadi, M.; Field, C.J.; Lehner, R.; Mazurak, V.C. Chemotherapy diminishes lipid storage capacity of adipose tissue in a preclinical model of colon cancer. Lipids Heal. Dis. 2017, 16, 247. [CrossRef] [PubMed]

135. Cai, F.; Sorg, O.; Granci, V.; Lecumberri, E.; Miralbell, R.; Dupertuis, Y.M.; Pichard, C. Interaction of $\omega-3$ polyunsaturated fatty acids with radiation therapy in two different colorectal cancer cell lines. Clin. Nutr. 2014, 33, 164-170. [CrossRef] [PubMed]

136. Granci, V.; Cai, F.; Lecumberri, E.; Clerc, A.; Dupertuis, Y.M.; Pichard, C. Colon cancer cell chemosensitisation by fish oil emulsion involves apoptotic mitochondria pathway. Br. J. Nutr. 2012, 109, 1188-1195. [CrossRef]

137. Golkhalkhali, B.; Rajandram, R.; Paliany, A.S.; Ho, G.F.; Ishak, W.Z.W.; Johari, C.S.; Chin, K.F. Strain-specific probiotic (microbial cell preparation) and omega-3 fatty acid in modulating quality of life and inflammatory markers in colorectal cancer patients: A randomized controlled trial. Asia Pac. J. Clin. Oncol. 2017, 14, 179-191. [CrossRef]

138. Siriwardhana, N.; Kalupahana, N.S.; Cekanova, M.; Lemieux, M.; Greer, B.; Moustaid-Moussa, N. Modulation of adipose tissue inflammation by bioactive food compounds. J. Nutr. Biochem. 2013, 24, 613-623. [CrossRef]

139. Mileo, A.M.; Nisticò, P.; Miccadei, S. Polyphenols: Immunomodulatory and Therapeutic Implication in Colorectal Cancer. Front. Immunol. 2019, 10, 729. [CrossRef]

140. Dykes, L. Phenolic Compounds in Cereal Grains and Their Health Benefits. Cereal Foods World 2007, 52, 105-111. [CrossRef] 
141. Vanamala, J.; Leonardi, T.; Patil, B.S.; Taddeo, S.S.; Murphy, M.E.; Pike, L.M.; Chapkin, R.S.; Lupton, J.R.; Turner, N.D. Suppression of colon carcinogenesis by bioactive compounds in grapefruit. Carcinogenesis 2005, 27, 1257-1265. [CrossRef] [PubMed]

142. Zhang, L.; Davies, S.S. Microbial metabolism of dietary components to bioactive metabolites: Opportunities for new therapeutic interventions. Genome Med. 2016, 8, 46. [CrossRef]

143. Miene, C.; Klenow, S.; Veeriah, S.; Richling, E.; Glei, M. Impact of apple polyphenols onGSTT2gene expression, subsequent protection of DNA and modulation of proliferation using LT97 human colon adenoma cells. Mol. Nutr. Food Res. 2009, 53, 1254-1262. [CrossRef] [PubMed]

144. Rechner, A. Colonic metabolism of dietary polyphenols: Influence of structure on microbial fermentation products. Free. Radic. Boil. Med. 2004, 36, 212-225. [CrossRef] [PubMed]

145. Cardona, F.; Andres-Lacueva, C.; Tulipani, S.; Tinahones, F.J.; Queipo-Ortuño, M.I. Benefits of polyphenols on gut microbiota and implications inhuman health. J. Nutr. Biochem. 2013, 24, 1415-1422. [CrossRef] [PubMed]

146. Dueñas, M.; Muñoz-Gonzalez, I.; Cueva, C.; Jiménez-Girón, A.; Sánchez-Patán, F.; Santos-Buelga, C.; Moreno-Arribas, M.V.; Bartolomé, B. A Survey of Modulation of Gut Microbiota by Dietary Polyphenols. BioMed Res. Int. 2015, 2015, 1-15. [CrossRef]

147. Clemente, J.C.; Ursell, L.K.; Parfrey, L.W.; Knight, R. The impact of the gut microbiota on human health: An integrative view. Cell 2012, 148, 1258-1270. [CrossRef]

148. Sánchez, M.D.C.; Ribeiro-Vidal, H.; Esteban-Fernández, A.; Bartolomé, B.; Figuero, E.; Moreno-Arribas, M.V.; Sanz, M.; Herrera, D. Antimicrobial activity of red wine and oenological extracts against periodontal pathogens in a validated oral biofilm model. BMC Complement. Altern. Med. 2019, 19, 145. [CrossRef]

149. Cueva, C.; Silva, M.; Pinillos, I.; Bartolomé, B.; Moreno-Arribas, M.V. Interplay between Dietary Polyphenols and Oral and Gut Microbiota in the Development of Colorectal Cancer. Nutrients 2020, 12, 625. [CrossRef]

150. Gibellini, L.; Pinti, M.; Nasi, M.; Montagna, J.P.; de Biasi, S.; Roat, E.; Bertoncelli, L.; Cooper, E.L.; Cossarizza, A. Quercetin and Cancer Chemoprevention. Evid. Based Complement. Altern. Med. 2011, 2011, 1-15. [CrossRef]

151. Venâncio, V.P.; Cipriano, P.A.; Kim, H.; Antunes, L.M.G.; Talcott, S.T.; Mertens-Talcott, S.U. Cocoplum (Chrysobalanus icaco L.) anthocyanins exert anti-inflammatory activity inhuman colon cancer and non-malignant colon cells. Food Funct. 2017, 8, 307-314. [CrossRef] [PubMed]

152. Lee, Y.; Sung, B.; Kang, Y.J.; Kim, N.H.; Jang, J.-Y.; Hwang, S.Y.; Kim, M.; Lim, H.S.; Yoon, J.-H.; Chung, H.Y.; et al. Apigenin-induced apoptosis is enhanced by inhibition of autophagy formation in HCT116 human colon cancer cells. Int. J. Oncol. 2014, 44, 1599-1606. [CrossRef] [PubMed]

153. Paul, S.; de Castro, A.J.; Lee, H.J.; Smolarek, A.K.; So, J.Y.; Simi, B.; Wang, C.X.; Zhou, R.; Rimando, A.M.; Suh, N. Dietary intake of pterostilbene, a constituent of blueberries, inhibits the $\beta$-catenin/p65 downstream signaling pathway and colon carcinogenesis in rats. Carcinogenesis 2010, 31, 1272-1278. [CrossRef] [PubMed]

154. Cui, X.; Jin, Y.; Hofseth, A.B.; Pena, E.; Habiger, J.; Chumanevich, A.; Poudyal, D.; Nagarkatti, M.; Nagarkatti, P.S.; Singh, U.P.; et al. Resveratrol suppresses colitis and colon cancer associated with colitis. Cancer Prev. Res. 2010, 3, 549-559. [CrossRef] [PubMed]

155. Rodríguez-Ramiro, I.; Ramos, S.; López-Oliva, E.; Agis-Torres, A.; Bravo, L.; Goya, L.; Martín, M. Ángeles Cocoa polyphenols prevent inflammation in the colon of azoxymethane-treated rats and in TNF- $\alpha$-stimulated Caco-2 cells. Br. J. Nutr. 2012, 110, 206-215. [CrossRef]

156. Majumdar, A.P. Preclinical animal tumor models to study prevention of colon cancer recurrence by curcumin. Anim. Models Cancer Drug Discov. 2019, 293-307. [CrossRef]

157. Simons, C.C.J.M.; Hughes, L.A.; Arts, I.C.; Goldbohm, R.A.; Brandt, P.A.V.D.; Weijenberg, M.P. Dietary flavonol, flavone and catechin intake and risk of colorectal cancer in the Netherlands Cohort Study. Int. J. Cancer 2009, 125, 2945-2952. [CrossRef]

158. Zamora-Ros, R.; Barupal, D.K.; Rothwell, J.A.; Jenab, M.; Fedirko, V.; Romieu, I.; Aleksandrova, K.; Overvad, K.; Kyrø, C.; Tjønneland, A.; et al. Dietary flavonoid intake and colorectal cancer risk in the European prospective investigation into cancer and nutrition (EPIC) cohort. Int. J. Cancer 2017, 140, 1836-1844. [CrossRef]

159. Nimptsch, K.; Zhang, X.; Cassidy, A.; Song, M.; O’Reilly, ÉJ.; Lin, J.H.; Pischon, T.; Rimm, E.B.; Willett, W.C.; Fuchs, C.S.; et al. Habitual intake of flavonoid subclasses and risk of colorectal cancer in 2 large prospective cohorts. Am. J. Clin. Nutr. 2015, 103, 184-191. [CrossRef] 
160. Xavier, C.P.R.; Lima, C.F.; Rohde, M.; Pereira-Wilson, C. Quercetin enhances 5-fluorouracil-induced apoptosis in MSI colorectal cancer cells through p53 modulation. Cancer Chemother. Pharmacol. 2011, 68, 1449-1457. [CrossRef]

161. Hakim, L.; Alias, E.; Makpol, S.; Ngah, W.Z.W.; Morad, N.A.; Yusof, Y.A.M. Gelam Honey and Ginger Potentiate the Anti Cancer Effect of 5-FU against HCT 116 Colorectal Cancer Cells. Asian Pac. J. Cancer Prev. 2014, 15, 4651-4657. [CrossRef] [PubMed]

162. Montrose, D.C.; Horelik, N.A.; Madigan, J.P.; Stoner, G.D.; Wang, L.-S.; Bruno, R.S.; Park, H.J.; Giardina, C.; Rosenberg, D.W. Anti-inflammatory effects of freeze-dried black raspberry powder in ulcerative colitis. Carcinogenesis 2010, 32, 343-350. [CrossRef] [PubMed]

163. McFadden, R.-M.; Larmonier, C.B.; Shehab, K.W.; Midura-Kiela, M.; Ramalingam, R.; Harrison, C.; Besselsen, D.G.; Chase, J.H.; Caporaso, J.G.; Jobin, C.; et al. The Role of Curcumin in Modulating Colonic Microbiota During Colitis and Colon Cancer Prevention. Inflamm. Bowel Dis. 2015, 21, 2483-2494. [CrossRef] [PubMed]

164. Shakibaei, M.; Buhrmann, C.; Kraehe, P.; Shayan, P.; Lueders, C.; Goel, A. Curcumin Chemosensitizes 5-Fluorouracil Resistant MMR-Deficient Human Colon Cancer Cells in High Density Cultures. PLoS ONE 2014, 9, e85397. [CrossRef] [PubMed]

165. Buhrmann, C.; Shayan, P.; Kraehe, P.; Popper, B.; Goel, A.; Shakibaei, M. Resveratrol induces chemosensitization to 5-fluorouracil through up-regulation of intercellular junctions, Epithelial-to-mesenchymal transition and apoptosis in colorectal cancer. Biochem. Pharmacol. 2015, 98, 51-68. [CrossRef] [PubMed]

166. Wang, Z.; Zhang, L.; Ni, Z.; Sun, J.; Gao, H.; Cheng, Z.; Xu, J.; Qiu, Y. Resveratrol induces AMPK-dependent MDR1 inhibition in colorectal cancer HCT116/L-OHP cells by preventing activation of NF- $\mathrm{kB}$ signaling and suppressing cAMP-responsive element transcriptional activity. Tumor Boil. 2015, 36, 9499-9510. [CrossRef] [PubMed]

167. Ohara, T.; Yoshino, K.; Kitajima, M. Possibility of preventing colorectal carcinogenesis with probiotics. Hepatogastroenterology 2011, 57, 1411-1415.

168. Drago, L. Probiotics and Colon Cancer. Microorganisms 2019, 7, 66. [CrossRef]

169. Hatakka, K.; Holma, R.; El-Nezami, H.; Suomalainen, T.; Kuisma, M.; Saxelin, M.; Poussa, T.; Mykkänen, H.; Korpela, R. The influence of Lactobacillus rhamnosus LC705 together with Propionibacterium freudenreichii ssp. shermanii JS on potentially carcinogenic bacterial activity inhuman colon. Int. J. Food Microbiol. 2008, 128, 406-410. [CrossRef]

170. Lin, C.; Cai, X.; Zhang, J.; Wang, W.; Sheng, Q.; Hua, H.; Zhou, X. Role of Gut Microbiota in the Development and Treatment of Colorectal Cancer. Digesiton 2018, 100, 72-78. [CrossRef]

171. Vinderola, G.; Perdigon, G.; Duarte, J.; Farnworth, E.; Matar, C. Effects of the oral administration of the exopolysaccharide produced by Lactobacillus kefiranofaciens on the gut mucosal immunity. Cytokine 2006, 36, 254-260. [CrossRef] [PubMed]

172. Galdeano, C.M.; Perdigón, G. The Probiotic Bacterium Lactobacillus casei Induces Activation of the Gut Mucosal Immune System through Innate Immunity. Clin. Vaccine Immunol. 2006, 13, 219-226. [CrossRef] [PubMed]

173. Bozkurt, H.S.; Quigley, E.M.; Kara, B. Bifidobacterium animalissubspecieslactisengineered to produce mycosporin-like amino acids in colorectal cancer prevention. SAGE Open Med. 2019, 7. [CrossRef]

174. Shi, Z.; Wang, S.; Ma, L.; Lu, W.; Zhao, X.; Yang, Y.; Li, X.; Wang, H.; Sun, W. Acupuncture: How objective is the evidence from randomised clinical trials? BJOG Int. J. Obstet. Gynaecol. 2011, 118, 1141-1142. [CrossRef]

175. Rafter, J.; Bennett, M.; Caderni, G.; Clune, Y.; Hughes, R.; Karlsson, P.C.; Klinder, A.; O'Riordan, M.; O'Sullivan, G.C.; Pool-Zobel, B.; et al. Dietary synbiotics reduce cancer risk factors in polypectomized and colon cancer patients. Am. J. Clin. Nutr. 2007, 85, 488-496. [CrossRef] [PubMed]

176. Hibberd, A.; Lyra, A.; Ouwehand, A.C.; Rolny, P.; Lindegren, H.; Cedgård, L.; Wettergren, Y. Intestinal microbiota is altered in patients with colon cancer and modified by probiotic intervention. BMJ Open Gastroenterol. 2017, 4, e000145. [CrossRef]

177. Liang, S.; Xu, L.; Zhangab, D.; Wu, Z. Effect of probiotics on small intestinal bacterial overgrowth in patients with gastric and colorectal cancer. Turk. J. Gastroenterol. 2016, 27, 227-232. [CrossRef] 
178. Wan, Y.; Xin, Y.; Zhang, C.; Wu, D.; Ding, D.; Tang, L.; Owusu, L.; Bai, J.; Li, W. Fermentation supernatants of Lactobacillus delbrueckii inhibit growth of human colon cancer cells and induce apoptosis through a caspase 3-dependent pathway. Oncol. Lett. 2014, 7, 1738-1742. [CrossRef]

179. Konishi, H.; Fujiya, M.; Tanaka, H.; Ueno, N.; Moriichi, K.; Sasajima, J.; Ikuta, K.; Akutsu, H.; Tanabe, H.; Kohgo, Y. Probiotic-derived ferrichrome inhibits colon cancer progression via JNK-mediated apoptosis. Nat. Commun. 2016, 7, 12365. [CrossRef] [PubMed]

180. Pouncey, A.L.; Scott, A.J.; Alexander, J.L.; Marchesi, J.R.; Kinross, J.M. Gut microbiota, chemotherapy and the host: The influence of the gut microbiota on cancer treatment. Ecancermedicalscience 2018, 12, 868. [CrossRef]

181. Iida, N.; Dzutsev, A.; Stewart, C.A.; Smith, L.; Bouladoux, N.; Weingarten, R.A.; Molina, D.A.; Salcedo, R.; Back, T.; Cramer, S.; et al. Commensal Bacteria Control Cancer Response to Therapy by Modulating the Tumor Microenvironment. Science 2013, 342, 967-970. [CrossRef] [PubMed]

182. Chang, C.-W.; Liu, C.-Y.; Lee, H.-C.; Huang, Y.-H.; Li, L.-H.; Chiau, J.-S.C.; Wang, T.-E.; Chu, C.-H.; Shih, S.-C.; Tsai, T.-H.; et al. Lactobacillus casei Variety rhamnosus Probiotic Preventively Attenuates 5-Fluorouracil/Oxaliplatin-Induced Intestinal Injury in a Syngeneic Colorectal Cancer Model. Front. Microbiol. 2018, 9, 983. [CrossRef] [PubMed]

183. Ding, C.; Tang, W.; Fan, X.; Wu, G. Intestinal microbiota: A novel perspective in colorectal cancer biotherapeutics. Onco Targets Ther. 2018, 11, 4797-4810. [CrossRef] [PubMed]

184. Lee, V.; Le, D.T. Efficacy of PD-1 blockade in tumors with MMR deficiency. Immunotherapy 2016, 8, 1-3. [CrossRef]

185. Routy, B.; le Chatelier, E.; de Rosa, L.; Duong, C.P.; Alou, M.T.; Daillère, R.; Fluckiger, A.; Messaoudene, M.; Rauber, C.; Roberti, M.P.; et al. Gut microbiome influences efficacy of PD-1-based immunotherapy against epithelial tumors. Science 2017, 359, 91-97. [CrossRef] [PubMed]

186. Österlund, P.; Ruotsalainen, T.; Korpela, R.; Saxelin, M.; Ollus, A.; Valta, P.; Kouri, M.; Elomaa, I.; Joensuu, H. Lactobacillus supplementation for diarrhoea related to chemotherapy of colorectal cancer: A randomised study. Br. J. Cancer 2007, 97, 1028-1034. [CrossRef]

187. Packey, C.D.; A Ciorba, M. Microbial influences on the small intestinal response to radiation injury. Curr. Opin. Gastroenterol. 2010, 26, 88-94. [CrossRef]

(C) 2020 by the authors. Licensee MDPI, Basel, Switzerland. This article is an open access article distributed under the terms and conditions of the Creative Commons Attribution (CC BY) license (http://creativecommons.org/licenses/by/4.0/). 